After-school care and parents' labor supply

Christina Felfe, Michael Lechner, Petra Thiemann

November 2013 Discussion Paper no. 2013-34 
Editor:

Publisher:

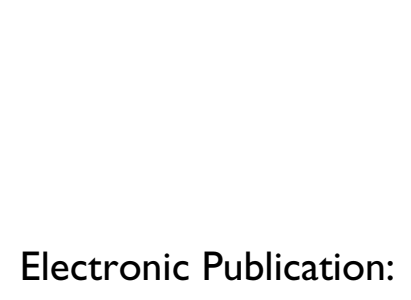

Martina Flockerzi

University of St. Gallen

School of Economics and Political Science

Department of Economics

Bodanstrasse 8

$\mathrm{CH}-9000$ St. Gallen

Phone +41712242325

Fax +41712243135

Email_seps@unisg.ch

School of Economics and Political Science

Department of Economics

University of St. Gallen

Bodanstrasse 8

$\mathrm{CH}-9000$ St. Gallen

Phone $\quad+41712242325$

Fax +41712243135

http://www.seps.unisg.ch 


\title{
After-school care and parents' labor supply ${ }^{1}$
}

\author{
Christina Felfe, Michael Lechner, Petra Thiemann²
}

Author's address:

Prof. Dr. Michael Lechner

Swiss Institute for Empirical Economic Research (SEW-HSG)

Varnbüelstrasse 14

$\mathrm{CH}-9000$ St. Gallen

Phone $\quad+41712242814$

Fax $\quad+41712242302$

Email michael.lechner@unisg.ch

Website www.sew.unisg.ch

Prof. Dr. Christina Felfe

Swiss Institute for Empirical Economic Research (SEW-HSG)

Varnbüelstrasse 14

$\mathrm{CH}-9000$ St. Gallen

Phone $\quad+41712242329$

Fax $\quad+41712242302$

Email christina.felfe@unisg.ch

Website www.sew.unisg.ch

Petra Thiemann

Department of Economics, University of St.Gallen

Bodanstrasse 8

$\mathrm{CH}-9000$ St. Gallen

Email petra.thiemann@unisg.ch

\footnotetext{
${ }^{1}$ This project received financial support from the Swiss National Science Foundation (SNF-NFP60 grant \# 406040-129248). We thank Infras, Zurich, for the provision of the data on child care availability in Switzerland, and Massimo Mannino for valuable research assistance. A previous version of the paper was presented at the University of St. Gallen. We thank participants, in particular Eva Deuchert and Jochen Mankart for helpful comments and suggestions. The usual disclaimer applies.

${ }^{2}$ Christina Felfe is also affiliated with CESIfo, Munich. Michael Lechner is also affiliated with CEPR and PSI, London, CESIfo, Munich, IAB, Nuremberg, and IZA, Bonn.
} 


\begin{abstract}
Does after-school care provision promote mothers' employment and balance the allocation of paid work among parents of schoolchildren? We address this question by exploiting variation in cantonal (state) regulations of after-school care provision in Switzerland. To establish exogeneity of cantonal regulations with respect to employment opportunities and preferences of the population, we restrict our analysis to confined regions along cantonal borders. Using semi-parametric instrumental variable methods, we find a positive impact of after-school care provision on mothers' full-time employment, but a negative impact on fathers' full-time employment. Thus, the supply of after-school care fosters a convergence of parental working hours.
\end{abstract}

\title{
Keywords
}

Childcare, parents' labor supply, semi-parametric estimation methods.

\section{JEL Classification}

$\mathrm{J} 13, \mathrm{~J} 22, \mathrm{C} 14$. 


\section{Introduction}

The $21^{\text {st }}$ century is characterized by an unprecedented participation of women with children in the labor market. In 2009, the average employment rate among women with children under the age of 15 amounted to $66.2 \%$ in the OECD (OECD, 2012). Yet, looking at the intensive margin the picture looks slightly less promising: in 2009 , only $44.6 \%$ of all employed women with children under the age of 15 worked full-time, while $26.1 \%$ had a workload of 50-90\% (3-4 days per week) and 29.4\% worked less than 50\%. In comparison, men with children under the age of 15 worked mostly fulltime $(78.4 \%)$. Given the existing evidence on negative consequences of a reduced workload for women's career opportunities (Waldfogel, 1997; Bratti, Bono, \& Vuri, 2004; Felfe, 2012), many developed countries currently consider a move towards expanding the public ${ }^{2}$ supply of all-day schools and afterschool care provision (Kamette, 2011). Yet, it is still unclear whether the availability of afterschool care stimulates the employment of mothers. Similarly, we do not know how fathers' employment reacts to an increase in the provision of supplementary school care.

Answering these questions is challenging, as public care provision is frequently intertwined with further spending (and taxation) decisions of local authorities. Moreover, citizens' preferences, initiatives and voting behavior might simultaneously influence public care provision and labor supply decisions. As a result, it is not straightforward to isolate the causal impact of after-school care provision on parents' labor supply.

This paper exploits regional variation in after-school care provision in Switzerland to study the impact of such facilities on mothers' and fathers' labor supply. In Switzerland, labor

2 We use the term "public" childcare interchangeably with "publicly regulated" childcare. In other words, public childcare slots do not need to be necessarily publicly financed. For details, on the regulation and financing scheme of public childcare, please refer to Section 2. 
supply decisions within families still reflect rather traditional role models. ${ }^{3}$ At the same time, the country is currently revising its educational system and subsidizing the expansion of extrafamiliar childcare to promote maternal labor supply. ${ }^{4}$ In order to account for potential endogeneity of after-school care provision with respect to further efforts to stimulate maternal labor supply, we exploit variation in cantonal (state) regulations of after-school care provision. Based on these regulations, we construct an instrumental variable (IV) for local after-school care provision. We additionally restrict our analysis to confined areas along cantonal borders, which we denote as "local labor markets" (LLMs). Doing so helps us to establish exogeneity of cantonal regulations with respect to the available labor market opportunities as well as to the preferences of the population under study.

Our results reveal a positive impact of after-school care provision on mothers' full-time employment, but a negative impact on fathers' full-time employment. In particular, an increase in after-school care provision by on average 8 percentage points (henceforth "ppt") leads to an average increase in mothers' full-time employment by 8 ppt. In contrast, the same increase in after-school care provision crowds out fathers' full-time employment by $10 \mathrm{ppt}$.

The idea of exploiting geographic borders to uncover the effects of policy interventions has already been used by Card and Krueger (1994), Holmes (1998), Black (1999), or Pence (2006), among others. The common argument is that while policies change abruptly at the border, the economic environment changes only very little. In other words, crossing the

3 In 2010 , in only $11 \%$ of all two-parent families with primary school children (4-12 years old) both parents worked fulltime, in $47 \%$ the mother worked part-time and the father worked full-time, and in $28 \%$ the mother was not employed at all, but only the father worked full-time. These numbers are based on own calculations using the Swiss Structural Survey. Please refer to Section 4 for more details on the data.

4 On February 1, 2003, the Swiss government launched a national program subsidizing new childcare facilities as well as expansions of existing childcare facilities. Over the last decade, this program led to an increase of the supply in afterschool care slots by almost 20 ’000 slots. 
border changes the impact of the policy or the likelihood of being subjected to it, but does not have any direct effect on individual outcomes in the absence of the policy differences in a local neighborhood around such borders. A commonly used approach in the above-mentioned studies is to use the border to construct an IV and use a 2SLS type approach. Yet, such an approach is rather restrictive in case covariates are necessary to make the IV assumption credible. Most importantly, it assumes effect homogeneity and controls for all confounding covariates in a linear fashion. Since in our framework both assumptions are highly unrealistic, we use an approach in the spirit of Frölich and Lechner (2010). This approach is a semiparametric IV approach that allows for heterogeneous treatment effects across the LLMs and proposes specific aggregating schemes for the local effects.

Over the last decade, a series of studies has emerged that analyzes the consequences of providing childcare on mothers' labor supply. Most studies focus on the impact of childcare provision during children's preschool years. The seminal paper in this area is by Gelbach (2002). ${ }^{5}$ He uses quarter of birth indicators as instruments for childcare attendance in the US and finds that providing public childcare free of charge stimulates labor supply among married mothers by $6-15 \%$ and among single mothers by $6-24 \%$. A range of subsequent studies supports these early findings. Common identification strategies rely on regional and time variation in childcare supply (Berlinski \& Galiani, 2007; Nollenberger \& RodriguezPlanas, 2011; Schlosser, 2011) or on the introduction of a price subsidy for public care (Baker, Gruber, \& Milligan, 2008; Lefebvre \& Merrigan, 2008). A series of recent studies, however, finds that maternal labor supply is on average rather inelastic to an exogenous

5 There have been several earlier papers studying the impact of childcare prices on mothers' labor supply. Most of these papers estimate structural parameters of utility functions to derive mothers' labor supply elasticities and to predict the consequences of childcare subsidies (Blau \& Robins, 1988; Conelly, 1992; Michalopoulos, Robins, \& Garfinkel, 1992; Kimmel, 1998). The resulting estimates of mothers' labor supply elasticities with respect to childcare prices vary between 0 and -1.6 for married mothers 
increase in available public childcare. Only certain subgroups of mothers, such as single mothers or mothers in disadvantaged areas, react positively to an increase in public childcare (Cascio, 2009; Fitzpatrick, 2010; Goux \& Maurin, 2010; Havnes \& Mogstad, 2011). Fitzpatrick (2012) uses the example of the US to discuss the underlying reasons for the lack of consensus in the empirical findings. Besides methodological differences between studies, one crucial factor is the institutional and the socio-economic context in which public childcare is implemented or expanded. In light of increasing maternal employment, delayed childbearing ages, and rising educational attainment, the subset of mothers for whom an expansion in public childcare might have a stimulating effect, has potentially shrunk.

To the best of our knowledge, there is only one study that focuses on the effects of childcare for schoolchildren, namely Lundin et al. (2008). They, however, evaluate the effects of a price reduction of childcare for children age 0-9 years old in Sweden at a time when overall coverage with childcare was already very high $(80 \%)$. Their results reveal that subsidizing childcare has positive effects on overall maternal employment. Yet, for mothers of children age 5 years old and older, these effects are negligible in size.

Our study contributes to the existing literature in several ways. First, we evaluate the impact of expanding public care provision available for schoolchildren in a context of rather low initial levels - in Switzerland, the coverage rate is on average about 9\% among children age 4-12 years old. Thus, if levels have an impact on the magnitudes of the effects, our results might differ from those of Lundin et al. (2008). Second, we focus on fathers' employment as well. Doing so might shed some light on whether extra-familiar care helps to improve the allocation of paid work among partners and thus promotes the equality of men and women on the labor market. Third, we also consider the intensive margin. In the light of high maternal employment rates, but prevailing gender wage differences, this focus might help to discover changes of mothers' labor supply at margins relevant for women's career opportunities. 
Finally, we employ an econometric IV methodology so far not applied to this type of studies that allows for effect heterogeneity and flexible control of observable confounders.

The remainder of the paper is structured as follows. The next section provides an overview of the childcare system in Switzerland and the cantonal regulations of after-school care provision. Section 3 explains in detail the identification strategy and estimation method. Section 4 describes the data, while Section 5 shows the results and a series of robustness checks. Section 6 finally concludes and adds some policy recommendations.

\section{$2 \quad$ Childcare in Switzerland}

Family structure in Switzerland largely follows traditional role models: in only $11 \%$ of all two-parent families with primary schoolchildren (4-12 years old) both parents work fulltime, in $47 \%$ the mother is working part-time and the father works full-time, and in $28 \%$ the mother is not employed at all and the father works full-time. At the same time, the supply of extra-familiar care is slowly, but steadily increasing. In 2003, the Swiss government has launched a national program, which subsidizes new childcare facilities as well as expansions of existing childcare facilities during the first three years after establishment/expansion (independently on whether the provider is a public or a private entity). ${ }^{6}$ As a result, the availability of extra-familiar childcare centers has increased substantially over the last decade. In 2010, average coverage rates of extra-familiar care amounted to $15 \%$ among preschool children and to $9 \%$ among schoolchildren. ${ }^{7}$

6 The program has been launched on February 1, 2003. It is called Federal Law on Financial Support for Extra-Familiar Childcare („Bundesgesetz über Finanzhilfen für familienergänzende Kinderbetreuung”) and administered by the Ministry of Social Affairs (Bundesamt für Sozialversicherung).

7 This data stems from a recent data collection by Infras, Zurich, and the Swiss Institute of Empirical Economic Studies at the University of St. Gallen. It facilitates for the first time a national overview of childcare availability in Switzerland and thus allows for transparency and comparison across and within cantons. For details, please refer to Felfe, Lechner, Iten, 
Yet, there is substantial regional variation in childcare provision, with cantonal averages ranging from $1 \%$ to $23 \%$ for preschool children and from $1 \%$ to $43 \%$ for schoolchildren (see Figure 1). Where do the differences between cantons come from? Cantons differ substantially in the extent to which they support the provision of childcare (see Table I.1 in the Appendix for an overview). For instance, 19 out of 26 cantons explicitly state extrafamiliar childcare as one policy to support families in their cantonal legislation, 17 cantons provide information and counseling in preparing applications for subsidies from the federal government, and 15 cantons contribute financially to the provision of childcare facilities. ${ }^{8}$

Coverage rates vary not only across cantons, but also within cantons. For instance, in the canton Zurich $1 \%$ of all schoolchildren live in a municipality without any supplementary public care, while $54 \%$ of all schoolchildren live in a municipality where more than $10 \%$ of all schoolchildren can attend public supplementary care (see Figure 2). In contrast, in the canton Bern these shares correspond to $47 \%$ and $2 \%$, respectively. The underlying reason for such heterogeneity is that in different cantons different entities are responsible for regulating, licensing, and supervising the provision of childcare facilities. Depending on the canton, these rights and duties are either borne by the canton, the municipality or both together (see Table I.1 in the Internet Appendix for details).

Schwab, Stern, \& Thiemann (2013). Unfortunately, there are no data available during prior years, which prevent from any identification based on the expansion of after-school care supply over the years since implementation of the program.

8 Childcare costs are generally borne by parents. Public subsidies (from the canton or the municipality) are available to lowincome families and are paid independently from the childcare provider (in other words, public subsidies can be used to pay a slot in a publicly or a privately organized childcare institution). The availability and amount of public subsidies, however, varies greatly across and within cantons. Unfortunately, so far there are no reliable data on the availability or the amount of public subsidies. As such, our study can only provide estimates for the impact of the availability of childcare slots, but not on the impact of more or less subsidized slots. Yet, comparing Table A.1. in the Appendix and Table I.1 in the Internet Appendix reveals that financial support from the side of the canton is not systematically correlated with cantonal regulations regarding the supply of after-school care (our instrumental variable, described in more detail in Section 3). 
Figure 1: Coverage rates of after-school care by cantons (states) 2010

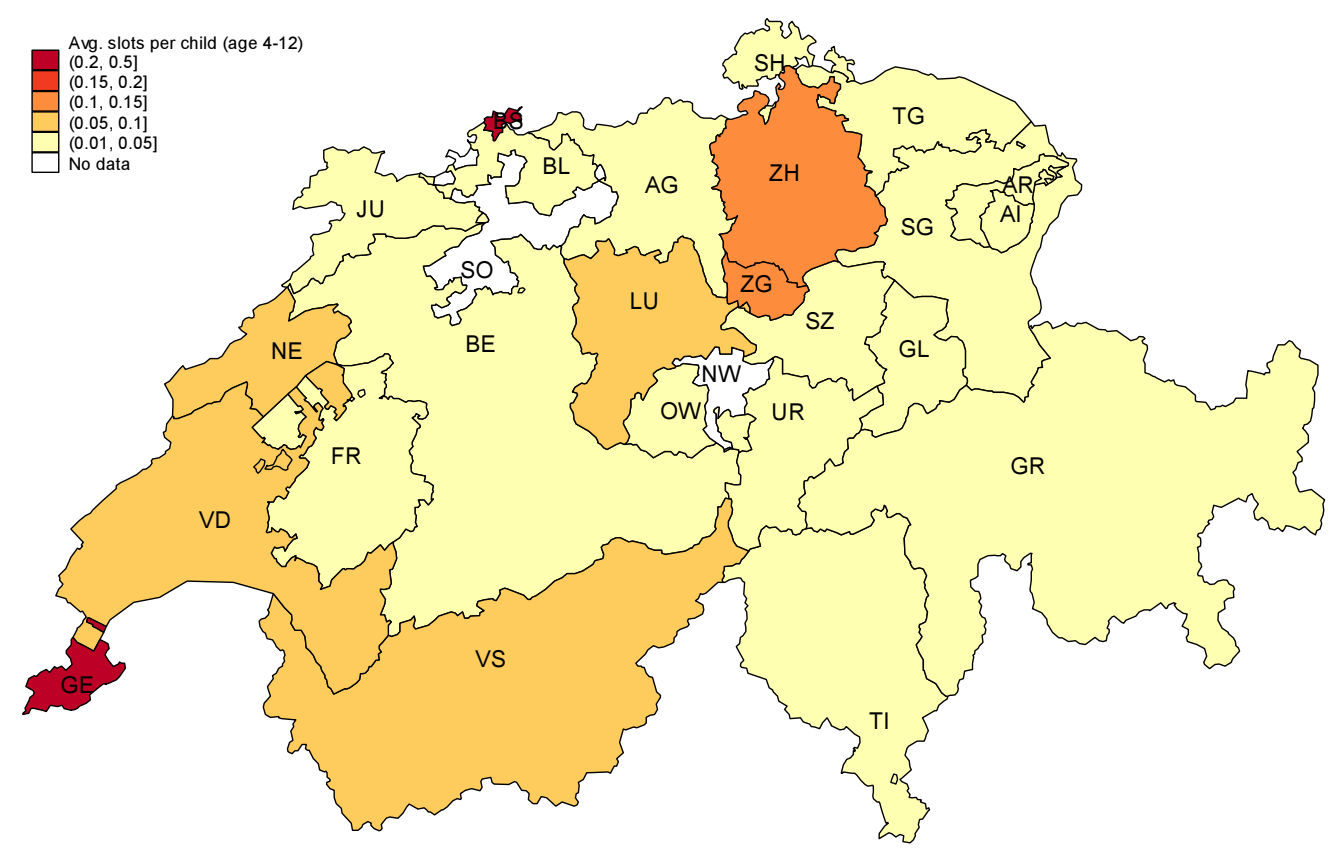

Source: Own calculations based on population survey 2010 and childcare database.

Figure 2: Coverage rates of after-school care by municipality in 2010

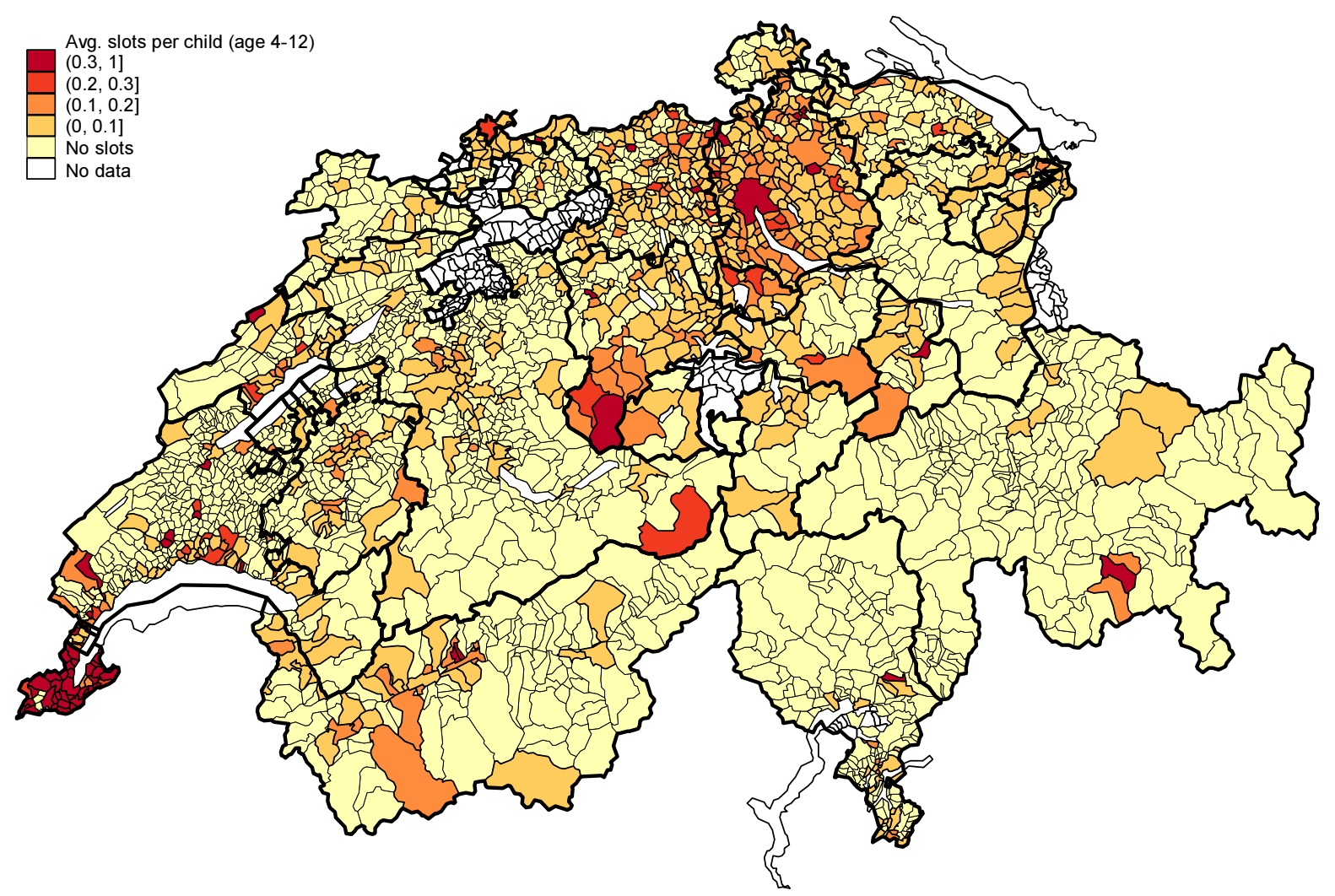

Source: Own calculations based on population survey 2010 and childcare database. 
In the course of reforming their cantonal legislations, in particular their school laws, ${ }^{9}$ several cantons have enforced the provision of supplementary care for schoolchildren available during lunchtime and afternoon hours. What motivates such a public intervention? The main argument is the prevailing gap between supply and demand regarding after-school care provision. Yet, what are the reasons for a market failure? First, a private solution at the family level comes at much higher variable costs per child than a solution in an organized after-school care facility where staff-child ratios are comparable to teacher-child ratios in primary school (1:15 and higher). Second, after-school care facilities face rather high fixed costs of setting up and running the business (e.g. provision of the infrastructure). In light of an initially potentially insufficient degree of capacity utilization and insecure returns in the following years, market entry barriers might be insurmountably high for private providers.

Table A.1 provides an overview of the cantonal school laws. ${ }^{10}$ Geneva was the first canton to enforce after-school care provision. Since 2007, cantons in the German language region are slowly catching up. By 2010, the base year of our empirical analysis, Bern, Solothurn and Zurich enforce the supply of supplementary after-school care. By then, also Aargau, Basel Land, and St. Gallen state lunch provision as one goal in their cantonal legislation, not, however, further care during afternoon hours. Further cantons such as Basel City, Graubünden, Lucerne, Neuchâtel, and Schaffhausen incorporate the call for after-school care provision only in later years. ${ }^{11}$

9 On May 21, 2006, the Swiss population and the council of States accepted the revision of the education article in the Swiss constitution. Consequently, all cantons are obliged to regulate certain elements of the education system (e.g. school entrance age, length of mandatory schooling). In addition, on August 1, 2009, the HarmoS-Konkordat came into force, which aims at harmonizing the Swiss educational system.

10 Table A.1 is based on a very careful reading and interpretation of the cantonal laws. We explicitly distinguish between laws only referring to childcare provision as one policy to promote families, requiring an inquiry of supply and demand of childcare, or enforcing the supply of sufficient childcare facilities. Only the latter is interpreted as 'legal enforcement'.

${ }^{11}$ Basel Land and Graubünden did so in 2011, Lucerne and Schaffhausen in 2012, and Neuchatel plans to do so in 2015. 


\section{Econometric Framework}

\subsection{Identification}

What is the impact of after-school care provision on parents' labor supply? The challenge in answering this question is that the amount of after-school care provision is likely to be intertwined with further efforts of the municipality and the local population to promote employment not only, but in particular, among parents. Offering childcare services represents one tool to improve the attractiveness of a municipality as a business location and/or to provide an attractive environment for high skilled (i.e. high tax paying) individuals. Further policies a municipality might undertake simultaneously are, for instance, reductions in corporate taxes or the development of new construction grounds. In addition, citizens might exert pressure on the municipality to increase the supply of childcare services. They might do so indirectly by electing politicians representing their preferences or directly by lobbying for initiatives to open up new childcare facilities. Thus, disentangling the effect of childcare supply on labor market outcomes from underlying preferences of the local population and simultaneous efforts of the municipality to increase the labor force attachment of its population or to attract work-oriented citizens is key for identifying causal effects of childcare provision on parental labor supply.

The variation across cantons in the legal enforcement of after-school care offers an opportunity to tackle the underlying endogeneity problem. As described in Section 2, some cantons legally enforce the provision of after-school care slots, while others at most mandate an inquiry of the supply and demand of after-school care slots. As a result, several cantonal borders represent a discontinuity in the probability that municipalities exert efforts to ensure the provision of sufficient after-school care slots. 
Our identification strategy relies on such discontinuities along several cantonal borders. To be more precise, we restrict our analysis to neighboring cantons that differ in the legal enforcement of after-school care supply and use their cantonal borders as an IV for the local supply of after-school care slots. Yet, for cantonal borders to be useful for uncovering the causal effects of after-school care provision on parents' labor supply, they must fulfill two conditions. First, the cantonal legislation must correlate with the actual supply of after-school care. In other words, coverage rates in cantons that legally enforce after-school care supply should not lie below the coverage rates in cantons that do not legally enforce after-school care supply. Section 5.1 provides empirical evidence supporting this condition. Second, cantonal borders should not mask any discontinuity in employment incentives except the discontinuity in the available after-school care services - hence, the IV should fulfill the "exclusion restriction". The latter condition is unlikely to hold in general as i) cantons differ in their industry structure and thus offer different employment opportunities, and ii) cantonal laws are the result of the actions of local authorities and reflect the preferences of the local population.

To address these two concerns we follow Frölich and Lechner (2010) and pursue the following strategy: we restrict our analysis to confined regions along cantonal borders, in particular to economically integrated local labor markets (henceforth LLMs). Appendix B describes in detail how we construct the LLMs and provides a map indicating the area of the LLMs (see Figure B.1).

We define a LLM as "integrated" if the value of different job opportunities does not depend on the location of residence within the LLM. In other words, all relevant employment opportunities are reachable within convenient commuting time (e.g. half an hour) from both sides of the border, such that the choice of workplace location and the choice of residence do 
not immediately depend on each other. Thus, we address the first concern - people residing on different sides of a cantonal border might face different employment opportunities. ${ }^{12}$

To address the second concern, we need to assure that the population residing within the LLM has no decisive weight in determining the cantonal legislation - hence, no majority of the cantonal population should reside in the respective municipalities. For this reason, we only consider LLMs, which do not comprise the majority of any of the respective cantonal populations (see Table 1, column 4 for evidence on this issue). ${ }^{13}$ In addition, inside any LLM the populations on both sides of the cantonal border should be similar in their preferences related to work and family. Yet, in at least one of the two cantons considered in each LLM there should be dissimilarity in these preferences between the populations residing inside and outside the LLM. This ensures that differences in the existing cantonal laws related to work and family might arise, but are unlikely to be driven by the population living in the municipalities belonging to the LLM. To provide evidence on this issue, we rely on the results of a recent referendum on maternity benefits (see Table 1, column 5). Indeed, results on this referendum are rather similar across the cantonal border within each LLM. Moreover, on at least one side of the cantonal border, the remaining cantonal population outvotes the population living in any municipality within the LLM.

12 Section 5.2 discusses furthermore the assumption that people within the LLM face equal employment opportunities by providing an overview of commuting time to major economic hubs from the municipalities on both sides of the cantonal border within the LLMs (see Table A.7).

13 There are two exceptions where the cantonal area included in the LLM covers more than $50 \%$ of overall canton (see LLM 5 and 7). In these cases, however, the wedge in the cantonal regulations regarding after-school care provision is caused by the other cantons (in both cases the municipalities lying outside the area included in the LLM in the canton Zurich). 
Table 1: Local labor markets: Relative size, political preferences and after-school care

\begin{tabular}{|c|c|c|c|c|c|c|}
\hline LLM & $\begin{array}{l}\text { Canton } \\
(1) \\
\end{array}$ & $\begin{array}{c}\text { IN/OUT* } \\
(2) \\
\end{array}$ & $\begin{array}{c}\text { \# of } \\
\text { municipalities }^{* *} \\
\text { (3) }\end{array}$ & $\begin{array}{c}\text { Population } \\
\text { share of } \\
\text { canton } \\
(4)\end{array}$ & $\begin{array}{l}\% \text { votes in } \\
\text { favor of } \\
\text { referendum } \\
\text { (5) }\end{array}$ & $\begin{array}{l}\text { After-school } \\
\text { care (slots } \\
\text { per child) } \\
(6)\end{array}$ \\
\hline \multirow{4}{*}{1} & \multirow{3}{*}{$\mathrm{BE}(\mathrm{IV}=1)$} & IN & 50 & $8.0 \%$ & $43.5 \%$ & 0.012 \\
\hline & & OUT & 336 & $92.0 \%$ & $55.1 \%$ & 0.027 \\
\hline & & $\mathbb{I N}$ & 53 & $37.4 \%$ & $38.7 \%$ & 0.027 \\
\hline & LU (IV=0) & OUT & 34 & $62.6 \%$ & $46.3 \%$ & 0.082 \\
\hline \multirow{4}{*}{2} & \multirow{3}{*}{$\mathrm{ZH}(\mathrm{IV}=1)$} & IN & 13 & $3.4 \%$ & $53.4 \%$ & 0.09 \\
\hline & & OUT & 158 & $96.6 \%$ & $53.4 \%$ & 0.145 \\
\hline & & $\mathbb{I N}$ & 14 & $43.2 \%$ & $51.5 \%$ & 0.09 \\
\hline & $\mathrm{LU}(\mathrm{IV}=0)$ & OUT & 73 & $56.8 \%$ & $37.3 \%$ & 0.04 \\
\hline \multirow{4}{*}{3} & \multirow{3}{*}{$\mathrm{ZH}(\mathrm{IV}=1)$} & $\mathbb{I N}$ & 24 & $9.3 \%$ & $49.5 \%$ & 0.087 \\
\hline & & OUT & 147 & $90.7 \%$ & $53.8 \%$ & 0.149 \\
\hline & & $\mathbb{I N}$ & 60 & $35.6 \%$ & $47.0 \%$ & 0.059 \\
\hline & $A G(I V=0)$ & OUT & 160 & $64.4 \%$ & $42.4 \%$ & 0.044 \\
\hline \multirow{4}{*}{4} & \multirow{3}{*}{$\mathrm{ZH}(\mathrm{IV}=1)$} & IN & 60 & $26.5 \%$ & $47.2 \%$ & 0.09 \\
\hline & & OUT & 111 & $73.5 \%$ & $55.7 \%$ & 0.164 \\
\hline & & $\mathbb{I N}$ & 40 & $27.3 \%$ & $49.3 \%$ & 0.070 \\
\hline & $A G(I V=0)$ & OUT & 180 & $72.7 \%$ & $42.0 \%$ & 0.042 \\
\hline \multirow{4}{*}{5} & \multirow{3}{*}{$\mathrm{ZH}(\mathrm{IV}=1)$} & IN & 79 & $22.6 \%$ & $49.6 \%$ & 0.107 \\
\hline & & OUT & 92 & $77.4 \%$ & $54.5 \%$ & 0.155 \\
\hline & & IN & 25 & $99.4 \%$ & $47.0 \%$ & 0.025 \\
\hline & $S H(I V=0)$ & OUT & 2 & $0.7 \%$ & $27.4 \%$ & 0.000 \\
\hline \multirow{4}{*}{6} & \multirow{3}{*}{$\mathrm{ZH}(\mathrm{IV}=1)$} & IN & 73 & $14.8 \%$ & $45.8 \%$ & 0.076 \\
\hline & & OUT & 98 & $85.2 \%$ & $54.7 \%$ & 0.157 \\
\hline & & $\mathbb{I N}$ & 28 & $35.8 \%$ & $40.1 \%$ & 0.031 \\
\hline & $\mathrm{TG}(\mathrm{IV}=0)$ & OUT & 52 & $64.2 \%$ & $39.1 \%$ & 0.027 \\
\hline \multirow{4}{*}{7} & \multirow{3}{*}{$\mathrm{ZH}(\mathrm{IV}=1)$} & IN & 22 & $5.5 \%$ & $48.2 \%$ & 0.068 \\
\hline & & OUT & 149 & $94.5 \%$ & $53.7 \%$ & 0.148 \\
\hline & & $\mathbb{I N}$ & 49 & $58.8 \%$ & $41.2 \%$ & 0.035 \\
\hline & $\mathrm{TG}(\mathrm{IV}=0)$ & OUT & 31 & $41.2 \%$ & $37.0 \%$ & 0.020 \\
\hline \multirow{4}{*}{8} & \multirow{3}{*}{$\mathrm{ZH}(\mathrm{IV}=1)$} & IN & 22 & $5.5 \%$ & $48.2 \%$ & 0.068 \\
\hline & & OUT & 149 & $94.5 \%$ & $53.7 \%$ & 0.148 \\
\hline & & $\mathbb{I N}$ & 10 & $13.7 \%$ & $41.0 \%$ & 0.019 \\
\hline & $S G(I V=0)$ & OUT & 75 & $86.3 \%$ & $41.6 \%$ & 0.017 \\
\hline
\end{tabular}

Note: $\quad{ }^{*}$ IN/OUT refer to the municipalities within a canton that do and do not belong to the respective LLM. ${ }^{* *}$ Number of municipalities excluded from labor markets: LM09: 3 municipalities, LM12: 11 municipalities, LM13: 14 municipalities, LM14: 2 municipalities, LM16: 2 municipalities, LM17: 6 municipalities, LM18: 2 municipalities, LM20: 2 municipalities. ${ }^{* *}$ Share of votes in favor of the referendum on maternity benefits on 26/09/ 2004. 


\subsection{Estimation}

The true effect of after-school care provision on parental labor supply may vary across individuals and LLMs. On the one hand, individuals' reaction to a change in available afterschool care may depend on their observable characteristics, such as education or income, and on their unobservable characteristics, such as their attitude towards sending their child to formal care. On the other hand, the treatment effect may vary depending on the institutional context, for instance, on the level of available after-school care. The reason for this might be that at different levels of, for instance, after-school care supply, different types of individuals decide to use after-school care. Since the level of after-school care supply varies across LLMs (see Table 1, column 6), treatment effects are likely to be heterogeneous.

To account for the latter source of effect heterogeneity, we pursue the analysis separately within each LLM. From a non-parametric perspective, one can consider the underlying estimations as separate cross-border comparisons for each LLM: within each LLM, we compare those living on one side of the border - where the canton legally enforces after-school care provision- with those residing on the other side - where the canton does not legally enforce after-school care provision. Given this setting and the likelihood of effect heterogeneity among individuals within LLMs, the non-parametric framework of the local average treatment effect (LATE) of Imbens and Angrist (1994) seems appropriate.

We implement the within-LLM IV estimation as a combination of the estimation approach by Frölich (2007), which extends the LATE framework by Imbens and Angrist (1994) to allow for control variables by matching on the propensity score, and the findings of the large-scale simulation study by Huber, Lechner, and Wunsch (2013). The resulting 
estimator corresponds to a ratio of two matching estimations, where the effect of the instrument on the outcome is divided by the effect of the instrument on the treatment. ${ }^{14}$

Since this method relies on a binary treatment, we need to define a cut-off that categorizes municipalities in areas with relatively high after-school care coverage - treated areas - and areas with relatively low after-school care coverage - control areas. Given the high variation in after-school care coverage (see Table 1, column 6), a single cut-off for all LLMs would result in a rather unequal distribution of treated and control areas within LLMs. We therefore define a separate cut-off for each LLM. We opt for the LLM-specific median as cut-off as doing so guarantees a similar number of treated and control observations in each LLM. The resulting cut-offs vary between coverage rates of $0.4 \%$ and $8.1 \%$ (see Table A.2). The difference between the average care coverage in municipalities below and equal to the cut-off and above the cut-off - the treatment intensity - amounts to $8 \mathrm{ppt}$ on average, but also varies across LLM (between 5 and 11 ppt, see Table A.2).

After estimating the effects for each LLM separately, we aggregate the different effects to increase precision. Since IV estimates are effects for subpopulations that react to a change in the instrument by changing their treatment status (so-called 'compliers'), our preferred weighting scheme is based on the number of compliers in the respective LLM. ${ }^{15}$ Alternative weighting schemes are based on: i) the number of compliers, but using only those LLMs where the estimates are within the logical range (in other words, the first stage is

${ }^{14}$ To compute the two matching estimators we use the bias-adjusted-radius-propensity-score matching approach. This estimator uses a parametric propensity score to remove the effect of observable confounders that might jeopardize the validity of the instrument. By using a parametric (probit) model for the link between instruments and instrument confounders only, and being otherwise fully nonparametric, such estimators avoid the 'curse of dimensionality' which is inherent to all non-parametric procedures, but at the same time retain most of their flexibility. The results on the probit estimations for each LLM are shown in Table I.2 in the Internet appendix.

15 Estimated by the denominator of the IV estimator times the number of observations. 
positive); ii) the number of observations of the respective LLM; and iii) the number of observations, but giving only positive weight to those LLMs for which the estimates are within their logical range. Inference is based on bootstrapping and the quantile method, i.e. bootstrapping the effects and considering their distribution to obtain the respective significance levels. Bootstrapping is implemented as a block bootstrap taking into account the possible correlation of individuals within the same municipality.

\section{Data}

Besides information on after-school care services, our analysis requires information on parents' labor supply. For this purpose, we draw upon the so-called structural survey 2010 ('Strukturerhebung 2010'). This survey is a supplement to the Swiss census 2010 and contains information on the employment status, both the extensive and intensive margin, as well as socio-demographic characteristics for around 200,000 randomly selected individuals among the permanent resident population age 15 years and older. Information on the municipality of residence allows us to merge information on the local availability of after-school care. In addition, we add information on further demographic and socio-economic conditions of the municipality, in particular the local results on the referendum on maternity benefits from 2004, provided by the Swiss Federal Statistical Office. Given our question of interest, we restrict our sample to the area covered by the LLMs, and then further to all working age (1862 years old) men and women, who have at least one child age 0-12 years old. ${ }^{16}$ The respective samples correspond to 10,133 men and 10,875 women.

16 The reason for considering men and women with children age 0-12 years old instead of men and women with children age 4-12 years old is that the knowledge about availability of care facilities for school-age children might influence men and women in their work arrangements already during children's preschool age. The structural survey only provides us with information on the children living in the household. Hence, our sample does not include parents whose children are living 
Our outcome variable is parents' labor supply. We distinguish between the extensive margin - whether parents work at all - and the intensive margin - whether parents work fulltime (more than 36 hours/week) or part-time (less or equal than 36 hours/week). We also distinguish between less than 20 hours/week (low part-time), between 21 and 27 hours/week (intermediate part-time), and between 28 and 36 hours/week (high part-time).

Table A.3 and A.4 provide some descriptive statistics regarding the labor supply for the female and male sample, respectively. $70 \%$ of all women in our sample are employed. Only $10 \%$ of these women work full-time, most work on a low part-time basis (38\%), followed by an intermediate part-time basis (16\%). Men, on the contrary, work mostly full-time (89\%) and only few men work part-time (8\%). In line with the expectation that a higher coverage rate of after-school care stimulates mothers' labor supply, mothers residing in treated areas, engage more in the labor market ( $72 \%$ versus $68 \%$ ). Moreover, they are observed to work more fulltime $(11 \%$ versus $9 \%)$ and part-time $(61 \%$ versus $58 \%)$. In contrast, in treated areas men are inclined to work slightly more part-time (9\% versus $7 \%)$, but slightly less full-time $(88 \%$ versus $91 \%)$.

Do treated and control municipalities differ along further dimensions? As we can see in Table A.3 and A.4, men and women living in treated areas are slightly better educated, but less likely to have children. In addition, women living in treated areas are also slightly more likely to be divorced. Treated areas are more urban and thus more densely populated, have a higher share of foreigners, a lower share of homeowners and commuters. As expected, a higher share of the population votes in favor of the referendum on maternity benefits, despite the fact that on average the referendum did not receive majority in these areas. 
These differences between the treated and control areas highlight the concern that after-school care supply is endogenous to the type of authorities and population living in a municipality and justifies the suggested IV approach.

\section{$5 \quad$ Results}

\subsection{Results}

Table 2 displays the baseline results. Panel A and B show the final effect estimates for females and males, respectively. The estimates are weighted averages of the LLM-specific estimates, where the weights correspond to the number of compliers of the respective LLM. ${ }^{17}$ Column 1 and 2 display the estimates of the mean potential outcome for men and women living in complier municipalities - municipalities that react to a cantonal enforcement of afterschool care provision - in the presence and absence of a cantonal enforcement of after-school care provision. Column 3 shows the estimated effect (computed as Column 2 - Column 1), while column 4 displays the $95 \%$ confidence interval.

To start with, a cantonal enforcement of after-school care provision induces a significant increase in after-school care availability. On average, a cantonal enforcement of after-school care provision implies for $46 \%$ of all women ( $43 \%$ of all men) in our sample that the municipality they are residing in raises its after-school care supply from below the median supply to above the median supply. What does this mean in terms of actual coverage rates? As shown in Table A.2, low supply municipalities - with an after-school care coverage below the LLM-specific cut-off - offer on average 3 slots per 100 children. In contrast, high supply municipalities - with an after-school care coverage above the LLM-specific cut-off - offer on

\footnotetext{
${ }^{17}$ Results using alternative aggregation schemes barely alter and are shown in the Internet Appendix, Table I.5-I.7.
} 
average 11 slots per 100 children. Thus, after a cantonal enforcement of after-school care availability, on average after-school care increases by 8 slots per 100 children.

Table 2: Results of IV Estimations- Sample of parents with children, age 0-12 years old

\begin{tabular}{|c|c|c|c|c|c|}
\hline \multirow{2}{*}{\multicolumn{2}{|c|}{$\begin{array}{c}\text { Potential outcome } \\
\text { (weighted avg.) in } \\
\text { complier } \\
\text { municipalities with } \\
\text { cantonal enforcement } \\
\text { (1) } \\
\end{array}$}} & \multirow{2}{*}{$\begin{array}{l}\text { Potential outcome } \\
\text { (weighted avg.) in } \\
\text { complier } \\
\text { municipalities w/o } \\
\text { cantonal enforcement } \\
\text { (2) }\end{array}$} & \multirow{2}{*}{$\begin{array}{l}\text { Treatment } \\
\text { effect } \\
\text { (weighted } \\
\text { avg.) } \\
\text { (3) }\end{array}$} & \multicolumn{2}{|c|}{$\begin{array}{c}95 \% \\
\text { Confidence } \\
\text { interval }\end{array}$} \\
\hline & & & & \multicolumn{2}{|c|}{ (4) } \\
\hline \multicolumn{6}{|c|}{ Panel A) Swiss women age 18-62 with children (age 0-12) } \\
\hline \multicolumn{6}{|l|}{ First stage estimates: } \\
\hline Effect of instrument on treatment & 0.67 & 0.22 & $0.45^{\star * *}$ & 0.31 & 0.57 \\
\hline \multicolumn{6}{|l|}{ LATE estimates: } \\
\hline Employment & 0.77 & 0.70 & 0.07 & -0.05 & 0.20 \\
\hline Full-time & 0.12 & 0.04 & $0.08^{* *}$ & 0.00 & 0.18 \\
\hline Part-time & 0.64 & 0.66 & -0.01 & -0.14 & 0.11 \\
\hline Low part-time & 0.44 & 0.43 & 0.01 & -0.14 & 0.14 \\
\hline Intermed. part-time & 0.14 & 0.16 & -0.02 & -0.18 & 0.10 \\
\hline High part-time & 0.06 & 0.06 & 0.00 & -0.06 & 0.08 \\
\hline \multicolumn{6}{|c|}{ Panel B) Swiss Men age 18-62 with children (age 0-12) } \\
\hline \multicolumn{6}{|l|}{ First Stage estimates: } \\
\hline Effect of instrument on treatment & 0.66 & 0.24 & $0.42^{\star * *}$ & 0.3 & 0.55 \\
\hline \multicolumn{6}{|l|}{ LATE estimates: } \\
\hline Employment & 0.94 & 0.96 & -0.02 & -0.10 & 0.02 \\
\hline Full-time & 0.87 & 0.96 & $-0.10^{* *}$ & -0.21 & -0.00 \\
\hline Part-time & 0.07 & 0.00 & 0.07 & -0.01 & 0.17 \\
\hline Low part-time & 0.03 & 0.00 & 0.02 & -0.01 & 0.08 \\
\hline Intermed. part-time & 0.01 & -0.02 & 0.02 & 0.00 & 0.06 \\
\hline High part-time & 0.04 & 0.01 & 0.03 & -0.03 & 0.08 \\
\hline $\begin{array}{ll}\text { Note: } & { }^{*} \text { significant at the } 1 \% \text {; } \\
& \text { weighted averages of the } \\
& \text { compliers in the respective } \\
\text { cantonal law. The sample } \\
\text { case of men. }\end{array}$ & $\begin{array}{l}\text { it at the } 5 \% \text {; }{ }^{*} \text { significan } \\
\text { tes for each LLM (LATE } \\
\text { ee instrument is based c } \\
\text { nds to } 10875 \text { observatic }\end{array}$ & $\begin{array}{l}\text { the } 10 \% \text { significanc } \\
\text { The underlying weig } \\
\text { the enforcement of a } \\
\text { in the case of wome }\end{array}$ & $\begin{array}{l}\text { vel Above } \\
\text { correspond } \\
\text { school car } \\
\text { nd } 101330\end{array}$ & $\begin{array}{l}\text { ates are } \\
\text { ee numb } \\
\text { oply in th }\end{array}$ & \\
\hline
\end{tabular}

What are the consequences of such an increase in after-school care for the labor force engagement of young parents? Overall, there is no statistically significant change in employment, neither for men nor for women. Yet, there is a statistically significant adjustment in full-time employment for both women and men. To be more precise, the increase in after-school care by 8 slots per 100 children leads to an increase in women's full- 
time employment of the same magnitude: full-time employment among women age 18-62 years old with children age $0-12$ years old rises from $4 \%$ to $12 \%$ on average. In contrast, men age 18-62 years old with children age 0-12 years old are observed to decrease full-time employment by 10 ppt. In particular, in a setting with 3 slots per 100 school-aged children in after-school care supply, $96 \%$ of the fathers work full-time, while in a setting with 11 slots only $87 \%$ of these fathers do so.

Unfortunately, the imprecision of the estimates for employment and part-time employment does not allow us to draw strong conclusions on where the adjustment in fulltime exactly comes from. In the case of women, it seems that there is a parallel increase in overall employment (by 7 ppt.) and a slight decrease in part-time employment (by 1 ppt.). In the case of men, the decrease in full-time employment seems to occur parallel to an increase in part-time (by 7 ppt., significant at the 15\% significance level) and a slight decrease of employment (by 2 ppt.). In any case, these estimates display the reaction of the (complier) population on average and do not allow any statement whether changes occur from no employment to part-time, part-time to full-time or even no employment to full-time

\subsection{Internal and External Validity}

Our analysis relies on exploiting cantonal borders as IV within the context of integrated LLMs. As discussed in Section 3.1, integrated LLM are constructed such that employment opportunities are independent of the exact location of residence within the LLM. Yet, one may doubt the internal validity of our results. In particular, one may question whether we can exclude any further differences in employment incentives present in different cantons. We therefore provide evidence of the absence of such differences, both in form of observables and unobservables. First, we discuss potential differences between income taxes, the education system or distance to major economic hubs (see Table A.5 - A.7, respectively). Second, we investigate whether an increase in after-school care stimulates the employment of 
a group on which it actually should have no impact: men and women under the age of 42 without children (see Table A.8) ${ }^{18}$ This placebo-type estimation allows us to test whether the cantonal borders under study might confound with general employment incentives that we cannot control for.

In Switzerland, income tax schemes fall into the jurisdiction of cantons. If income taxes are systematically lower in cantons enforcing the supply of after-school care, our estimation results might be biased upward (the incentive for engaging in the labor market might be due to lower taxes and not due to higher supply of after-school care). Table A.5 displays the average income taxes applying to a married couple with two children with an annual income of 100'000 CHF (as one example) on both sides of the cantonal border inside of each LLM. As we can see, in 6 out of 8 LLMs income taxes are slightly lower in the municipalities belonging to the canton where childcare provision is legally enforced. Nevertheless, differences are economically negligible (at most 1 ppt.) and thus are not likely to constitute a meaningful threat to our estimates.

In a similar vein to the tax system, systematic cantonal differences in the education system might invalidate our results. In particular, if children spend different amounts of time in school - either because they start school earlier or because school hours are longer - parents might be differently discharged from providing care. Yet, despite cantonal authority in educational issues preschool and primary school institutions do not seem to vary systematically across the cantons belonging to the eight LLM. As we can see in Table A.6, there are no systematic differences with respect to the length of preschool attendance, school

\footnotetext{
18 We restrict the placebo-sample to men and women under the age of 42 . We do so, as older people are more likely to have had children before. As a result, available childcare services might have affected their labor force engagement in the past. In addition, our dataset does not allow us to identify people who have children that already moved out. Since this is likely to be the case for people age 42 and older, we abstain from considering them in our placebo-type estimation.
} 
entry age or amount of school hours between the cantons in any of the LLMs. Hence, cantonal differences in the education system are also unlikely to constitute an important source of bias for our estimates.

Do citizens on one side of the cantonal border live systematically closer to economic hubs, which offer disproportionally more employment opportunities? As we can see in Table A.7, people residing in municipalities of the canton requiring after-school care provision in their cantonal laws live in fact closer to major economic hubs such as Zurich or Bern (on average, they need to commute a quarter of an hour less). Yet, people on the other side of the cantonal border need to commute substantially less to further important economic hubs (here represented by the capital of the second canton in the LLMs). As such, job opportunities should be comparable for all individuals residing in the same LLM.

The results of the suggested placebo-type estimation - estimating the effect of afterschool care availability for childless people - a group for whom we should not observe any effect - supports further the claim that there are no major differences in employment incentives across the cantonal borders. Table A.8 in the Appendix displays the results for the respective samples, Swiss men and women, age 18-42, without children. As we can see, the results on the different employment indicators are not only statistically insignificant, but also economically negligible. As such, we believe that there are no further relevant differences in employment incentives within the area of integrated LLMs.

Finally, selective migration induced by the presence of different cantonal laws related to after-school care constitutes one further threat to our identification strategy. In other words, if parents are aware of a slightly higher probability to have access to a slot in after-school care 
in the neighboring canton, they might decide to move. ${ }^{19}$ Yet, given the substantial costs of changing residence and the rather high uncertainty to benefit from the very low supply of after-school care, selective migration across cantonal borders seems unlikely. And indeed, empirical evidence corroborates this claim: there is no strong pattern pointing towards childcare supply being a driving factor of moving behavior (see Table A.9).

Besides internal validity, one might ask to which extent we can extrapolate our findings to contexts different to the one represented by our LLMs. To address this question, we need first to discuss to which extent 'complier' municipalities - those municipalities that react to a cantonal enforcement of after-school care provision - are comparable to the remaining municipalities inside the LLMs. In addition, we need to compare the features of the area covered by the LLM with the ones of the overall German speaking area of Switzerland. ${ }^{20}$

Regarding the first issue, the population residing in complier municipalities is - in terms of observable characteristics - not statistically different from the overall population residing in the area covered by the LLMs -, which constitutes $30 \%$ of the German speaking population in Switzerland. For instance, both populations do neither differ significantly in terms of their labor force attachment, nor in terms of socio-demographic characteristics (such as age, marital status, or education). Also, in terms of expressed preferences - measured by the results for the referendum on maternity benefits - both populations are comparable. Concerns, however, are more justified regarding the second issue - whether the population residing inside the LLM is representative for the overall German speaking population in Switzerland. As described in Section 3, our LLMs are chosen such that their population does not represent the majority of

\footnotetext{
19 Notice that the choice of school is tied to the location of residence. As a result the after-school care facility should ideally be at the location of residence.

${ }^{20}$ Descriptive statistics for all three samples are shown in Table I.3 and I.4 in the Internet Appendix.
} 
the cantonal population (hence, areas that include major cities are excluded). The resulting sample is therefore not representative for the urban parts, but only for the agglomeration and rural parts of the German speaking part of Switzerland. Nevertheless, the differences in socioeconomic and demographic characteristics between the two groups - the sample used in this study and overall Swiss Germany - are quite negligible.

\section{Conclusions}

The paper addresses the question whether after-school care provision can affect parental labor supply. Relying on cantonal regulations in after-school care provision as instruments, and using semi-parametric instrumental variable methods, we find that afterschool care provision increases full-time employment among mothers, but crowds out fulltime employment among fathers. As such, after-school care provision seems to contribute to the promotion of women in the labor market and thus, to an equal allocation of employment among parents.

Many developed countries are currently considering an expansion of the childcare system. Besides care provision for preschool children, supplementary care for schoolchildren receives increasing attention. Switzerland, for instance, has recently launched a federal program providing initial subsidies to new or expanding care institutions. Germany is currently debating to extend its school system and to offer an increasing amount of all-day schools. In light of maternal employment and career opportunities, this investment might pay off: our results indicate that each newly created after-school care slot causes one more mother to work full-time, as opposed to not working or working part-time. Yet, given the rather large confidence intervals of our estimates and the unknown general equilibrium effects, we abstain from providing a general policy recommendation. 


\section{Bibliography}

Baker, M., Gruber, J., \& Milligan, K. (2008). Universal Childcare, Maternal Labor Supply, and Family Well-being. Journal of Political Economy, 116, 709-745.

Berlinski, S., \& Galiani, S. (2007). The effect of a large expansion of pre-primary school facilities on preschool attendance and material employment. Institute for Fiscal Studies (IFS) Working Papers, 04/30.

Black, S. (1999). Do Better Schools Matter? Parental Valuation of Elementary Education. Quarterly Journal of Eco-nomics, 114, 577-599.

Blau, D., \& Robins, P. (1988). Child-care costs and family labor supply. The Review of Economics and Statistics, 70, 374-381.

Bratti, M., Bono, E. D., \& Vuri, D. (2004). New mothers' labour force participation in Italy: The role of job characteristcis. Labour, 19, 79-121.

Card, D., \& Krueger, A. (1994). Minimum Wages and Employment: A Case Study of the Fast-Food Industry in New Jersey and Pennsylvania. American Economic Review, 84, 772-793.

Cascio, E. (2009). Maternal Labor Supply and the Introduction of Kindergartens into American Public Schools. Journal of Human Resources, 74, 140-170.

Conelly, W. (1992). Agricultural intensification in a Philippine frontier community: impact on labor efficiency and farm diversity. Human Egology, 20, 203-223.

Felfe, C. (2012). The motherhood wage gap: What about job amenities. Labour Economics, 19, 59-67.

Felfe, C., Lechner, M., Iten, R., Schwab, S., Stern, S., \& Thiemann, P. (2013). Familienergänzende Kinderbetreuung und Gleichstellung. Bern: Schweizer Nationalfond.

Fitzpatrick, M. (2010). Preschoolers Enrolled and Mothers at Work? The Effects of Universal PreKindergarten. Journal of Labour Economics, 28, 51-85.

Fitzpatrick, M. (2012). Revising Our Thinking about the Relationship between Maternal Labor Supply and Preschool. Journal of Human Resources, 47, 583-612.

Frölich, M. (2007). Nonparametric IV estimation of local average treatment effects with covariates. Journal of Econometrics, 139, 35-75.

Frölich, M., \& Lechner, M. (2010). Exploiting Regional Treatment Intensity for the Evaluation of Labour Market Policies. Journal of American Statistical Association, 105, 1014-1029.

Gelbach, J.B.. (2002). Public schooling for young children and maternal labor supply. The American Economic Review, 92, 307-322.

Goux, D., \& Maurin, E. (2010). Public school availability for two-year olds and mothers' labour supply. Labour Economics, 17, 951-962.

Havnes, T., \& Mogstad, M. (2011). Money for Nothing? Universal Child Care and Maternal Employment. Journal of Public Economics, 95, 1455-1465.

Holmes, T. (1998). The Effect of State Policies on the Location of Manufacturing: Evidence from State Borders. Journal of Political Economy, 106, 667-705. 
Huber, M., Lechner, M., \& Wunsch, C. (2013). The Performance of Estimators Based on the Propensity Score. Journal of Econometrics, 175, 1-21.

Imbens, G., \& Angrist, J. (1994). Identification and estimation of local average treatment effects. Econometrica, 62, 467-475.

Kamette, F. (2011). Organisation of School Time in the European Union. Fondation Robert Schumann, Policy Paper, 212.

Kimmel, J. (1998). Child care costs as a barrier to employment for single and married mothers. Review of Economics and Statistics, 80, 287-299.

Lefebvre, P., \& Merrigan, P. (2008). Childcare Policy and the Labor Supply of Mothers with Young Children: A Natural Experiment from Canada. Journal of Labor Economics, 23, 519-548.

Lundin, D., Mörk, E., \& Öckert, B. (2008). How far can reduced childcare prices push female labour supply? Labour Economics, 15, 647-659.

Michalopoulos, C., Robins, P., \& Garfinkel, I. (1992). A structural model of labor supply and child care demand. Journal of Human Resources, 27, 166-203.

Nollenberger, N., \& Rodriguez-Planas, N. (2011). Child Care, Maternal Employment and Persistence: A Natural Experiment from Spain. IZA Discussion Paper, 5888.

OECD. (2012). OECD Family Database. www.oecd.org/social/family/database, accessed Sept., 9, 2013.

Pence, K. (2006). Foreclosing on Opportunity: State Laws and Mortgage Credit. Review of Economics and Statistics, 88, 177-182.

Schlosser, A. (2011). Public Preschool and the Labor Supply of Arab Mothers: Evidence from a Natural Experiment. mimeo.

Waldfogel, J. (1997). The effect of children on women's wages. American Sociological Review, 62, 209-217. 


\section{Appendix A}

Table A.1: Cantonal school reforms and enforcement of after-school care provision

\begin{tabular}{|c|c|c|c|c|}
\hline Canton & $\begin{array}{l}\text { Reform } \\
\text { (1) }\end{array}$ & $\begin{array}{l}\text { Lunch care } \\
\text { required by } \\
\text { new school law } \\
\text { (2) }\end{array}$ & $\begin{array}{l}\text { Afternoon care } \\
\text { required by new } \\
\text { school law } \\
\text { (3) }\end{array}$ & $\begin{array}{l}\text { Enforcement of after-school } \\
\text { care by } 2010 \\
\text { (4) }\end{array}$ \\
\hline AG & 2008 & Yes & No & No \\
\hline $\mathrm{Al}$ & - & - & - & No \\
\hline AR & - & - & - & No \\
\hline $\mathrm{BE}$ & 2008 & Yes & Yes & Yes \\
\hline$B L$ & 2003 & Yes & No & No \\
\hline BS & 2011 & Yes & Yes & No \\
\hline FR & - & - & - & No \\
\hline GE & 1997 & Yes & Yes & Yes \\
\hline GL & - & - & - & No \\
\hline GR & 2011 & Yes & Yes & No \\
\hline JU & - & - & - & No \\
\hline LU & 2012 & Yes & Yes & No \\
\hline $\mathrm{NE}$ & 2015 & $?$ & $?$ & No \\
\hline NW & - & - & - & No \\
\hline OW & - & - & - & No \\
\hline SG & 2008 & Yes & No & No \\
\hline SH & 2012 & Yes & Yes & No \\
\hline so & 2007 & Yes & Yes & Yes \\
\hline SZ & - & - & - & No \\
\hline TG & 2005 & No & No & No \\
\hline $\mathrm{TI}$ & - & - & - & No \\
\hline UR & - & - & - & No \\
\hline VD & - & - & - & No \\
\hline VS & - & - & - & No \\
\hline$Z G$ & - & - & - & No \\
\hline $\mathrm{ZH}$ & 2009 & Yes & Yes & Yes \\
\hline
\end{tabular}

Source: Own investigations based on cantonal laws/school laws (2012) 
Table A.2: Treatment intensity and cut-off definition

\begin{tabular}{|c|c|c|c|c|c|c|}
\hline \multicolumn{7}{|c|}{ Definition of cut-offs } \\
\hline \multirow[t]{2}{*}{ LLM } & $\begin{array}{c}\text { Above/below } \\
\text { cut-off }\end{array}$ & Obs. & Municipalities & $\begin{array}{l}\text { Cut-off (slots } \\
\text { per child) }\end{array}$ & $\begin{array}{l}\text { Average slots } \\
\text { per child }\end{array}$ & $\begin{array}{l}\text { Difference in } \\
\text { slots per child }\end{array}$ \\
\hline & (1) & (2) & (3) & (4) & (5) & (6) \\
\hline \multirow{2}{*}{1 BE-LU } & Above & 6848 & 22 & \multirow[t]{2}{*}{0.004} & 0.052 & \multirow[t]{2}{*}{0.052} \\
\hline & Below & 7670 & 81 & & 0.000 & \\
\hline \multirow{2}{*}{$2 \mathrm{ZH}-\mathrm{LU}$} & Above & 6325 & 10 & \multirow[t]{2}{*}{0.081} & 0.156 & \multirow[t]{2}{*}{0.110} \\
\hline & Below & 7439 & 17 & & 0.047 & \\
\hline \multirow{2}{*}{$3 \mathrm{ZH}-\mathrm{AG}$} & Above & 10577 & 43 & \multirow{2}{*}{0.050} & 0.106 & \multirow{2}{*}{0.081} \\
\hline & Below & 10614 & 41 & & 0.025 & \\
\hline \multirow{2}{*}{$4 \mathrm{ZH}-\mathrm{AG}$} & Above & 12915 & 51 & \multirow{2}{*}{0.069} & 0.120 & \multirow{2}{*}{0.081} \\
\hline & Below & 12799 & 49 & & 0.039 & \\
\hline \multirow{2}{*}{$5 \mathrm{ZH}-\mathrm{SH}$} & Above & 7138 & 36 & \multirow{2}{*}{0.068} & 0.145 & \multirow{2}{*}{0.110} \\
\hline & Below & 7242 & 68 & & 0.035 & \\
\hline \multirow{2}{*}{$6 \mathrm{ZH}-\mathrm{TG}$} & Above & 7287 & 50 & \multirow{2}{*}{0.040} & 0.092 & \multirow{2}{*}{0.074} \\
\hline & Below & 7495 & 51 & & 0.018 & \\
\hline \multirow{2}{*}{$7 \mathrm{ZH}-\mathrm{TG}$} & Above & 5695 & 24 & \multirow{2}{*}{0.040} & 0.084 & \multirow{2}{*}{0.070} \\
\hline & Below & 8321 & 47 & & 0.014 & \\
\hline \multirow{2}{*}{$8 \mathrm{ZH}-\mathrm{SG}$} & Above & 2746 & 12 & \multirow[t]{2}{*}{0.051} & 0.077 & \multirow[t]{2}{*}{0.063} \\
\hline & Below & 2861 & 20 & & 0.015 & \\
\hline \multirow{2}{*}{ Total } & Above & - & - & - & 0.108 & \multirow[t]{2}{*}{0.081} \\
\hline & Below & - & - & - & 0.026 & \\
\hline
\end{tabular}

Note: Average after-school care (slots per child in the age 4-12) in municipalities above and below the LLM-specific cutoffs, by LLM. Calculation is based on all observations in the population survey, sample restricted to individuals in the age 18-62. 
Table A.3: Descriptive statistics for Swiss women, age 18-62, with children age 0-12

\begin{tabular}{|c|c|c|c|c|c|}
\hline & $\begin{array}{l}\text { Pooled } \\
\text { sample }\end{array}$ & $\begin{array}{c}\text { Treated } \\
\text { areas }\end{array}$ & $\begin{array}{c}\text { Control } \\
\text { areas }\end{array}$ & \multicolumn{2}{|c|}{ Difference } \\
\hline & $(1)$ & $(2)$ & (3) & \multicolumn{2}{|c|}{ (4) } \\
\hline & Mean & Mean & Mean & Difference & p-val. \\
\hline \multicolumn{6}{|l|}{ Labor Market Outcomes } \\
\hline Employment (binary) & 0.70 & 0.72 & 0.68 & 0.04 & 0.000 \\
\hline Full-time & 0.10 & 0.11 & 0.09 & 0.01 & 0.017 \\
\hline Part-time & 0.60 & 0.61 & 0.58 & 0.03 & 0.003 \\
\hline Low part-time & 0.38 & 0.38 & 0.39 & -0.01 & 0.322 \\
\hline Intermediate part-time & 0.16 & 0.17 & 0.14 & 0.03 & 0.00 \\
\hline High part-time & 0.05 & 0.06 & 0.05 & 0.01 & 0.024 \\
\hline \multicolumn{6}{|l|}{ Treatment/Instrument } \\
\hline After-school care: Slots per child & 0.06 & 0.11 & 0.03 & 0.08 & 0.00 \\
\hline Reform canton (binary) & 0.32 & 0.56 & 0.28 & 0.28 & 0.00 \\
\hline \multicolumn{6}{|l|}{ Individual Control Variables } \\
\hline Age & 38.39 & 38.61 & 38.39 & 0.23 & 0.051 \\
\hline Mandatory education & 0.09 & 0.10 & 0.08 & 0.02 & 0.002 \\
\hline Secondary education & 0.55 & 0.53 & 0.58 & -0.05 & 0.000 \\
\hline Tertiary education & 0.35 & 0.36 & 0.33 & 0.03 & 0.003 \\
\hline Married & 0.89 & 0.89 & 0.89 & -0.01 & 0.405 \\
\hline Single & 0.07 & 0.06 & 0.07 & -0.01 & 0.260 \\
\hline Divorced & 0.04 & 0.05 & 0.04 & 0.01 & 0.017 \\
\hline Widowed & 0.01 & 0.01 & 0.01 & 0.00 & 0.455 \\
\hline Partner living in household & 0.94 & 0.94 & 0.94 & 0.00 & 0.327 \\
\hline Number of kids & 2.06 & 2.00 & 2.08 & -0.07 & 0.000 \\
\hline \multicolumn{6}{|l|}{ Regional Control variables } \\
\hline Vote share pro "Mutterschutz" (\%) & 0.45 & 0.48 & 0.43 & 0.05 & 0.000 \\
\hline Inhabitants & 14925 & 18064 & 7123 & 10942 & 0.000 \\
\hline Urban & 0.16 & 0.20 & 0.07 & 0.13 & 0.000 \\
\hline Agglomeration & 0.46 & 0.57 & 0.53 & 0.05 & 0.000 \\
\hline Rural & 0.38 & 0.23 & 0.41 & -0.18 & 0.000 \\
\hline Income tax (100K; married \& 2 kids, $\%$ ) & 6.62 & 6.30 & 6.56 & -0.26 & 0.000 \\
\hline Population density/100 m2 & 795 & 932 & 599 & 332 & 0.000 \\
\hline Fraction of foreigners (\%) & 17.89 & 19.46 & 16.48 & 2.98 & 0.000 \\
\hline Unemployment rate & 3.12 & 3.39 & 2.98 & 0.41 & 0.000 \\
\hline Home ownership in \% & 42 & 39 & 47 & -8 & 0.000 \\
\hline Fraction of commuters (\%) & 59 & 61 & 63 & -2 & 0.000 \\
\hline
\end{tabular}

Note: The sample is based on the structural survey 2010 and contains 10,875 observations. Treated areas are areas with a level of after-school care above the cut-off, control areas are areas with a level of after-school care below the cut-off 
Table A.4: Descriptive statistics for Swiss men, age 18-62, with children age 0-12

\begin{tabular}{|c|c|c|c|c|c|}
\hline & \multirow{2}{*}{$\begin{array}{c}\text { Pooled } \\
\text { sample } \\
\text { (1) } \\
\text { Mean }\end{array}$} & \multirow{2}{*}{$\begin{array}{c}\text { Treated } \\
\text { areas } \\
(2) \\
\text { Mean }\end{array}$} & \multirow{2}{*}{$\begin{array}{c}\text { Control } \\
\text { areas } \\
(3) \\
\text { Mean }\end{array}$} & \multicolumn{2}{|c|}{$\begin{array}{c}\text { Difference } \\
\text { (4) }\end{array}$} \\
\hline & & & & Difference & $\mathrm{p}$-val. \\
\hline \multicolumn{6}{|l|}{ Labor Market Outcomes } \\
\hline Employment (binary) & 0.97 & 0.97 & 0.98 & -0.01 & 0.031 \\
\hline Full-time & 0.89 & 0.88 & 0.91 & -0.02 & 0.000 \\
\hline Part-time & 0.08 & 0.09 & 0.07 & 0.02 & 0.004 \\
\hline Low part-time & 0.03 & 0.03 & 0.02 & 0.00 & 0.195 \\
\hline Intermediate part-time & 0.01 & 0.01 & 0.01 & 0.00 & 0.360 \\
\hline High part-time & 0.04 & 0.04 & 0.03 & 0.01 & 0.015 \\
\hline \multicolumn{6}{|l|}{ Treatment/Instrument } \\
\hline After-school care: Slots per child & 0.06 & 0.11 & 0.03 & 0.08 & 0.000 \\
\hline Reform canton (binary) & 0.32 & 0.56 & 0.29 & 0.27 & 0.000 \\
\hline \multicolumn{6}{|l|}{ Individual Control Variables } \\
\hline Age & 41.19 & 41.26 & 41.24 & 0.02 & 0.851 \\
\hline Mandatory education & 0.05 & 0.05 & 0.04 & 0.01 & 0.029 \\
\hline Secondary education & 0.39 & 0.37 & 0.40 & -0.03 & 0.002 \\
\hline Tertiary education & 0.54 & 0.56 & 0.54 & 0.02 & 0.024 \\
\hline Married & 0.94 & 0.94 & 0.95 & 0.00 & 0.395 \\
\hline Single & 0.04 & 0.04 & 0.04 & 0.00 & 0.451 \\
\hline Divorced & 0.01 & 0.01 & 0.01 & 0.00 & 0.778 \\
\hline Widowed & 0.00 & 0.00 & 0.00 & 0.00 & 0.123 \\
\hline Partner living in household & 0.99 & 0.99 & 0.99 & 0.00 & 0.537 \\
\hline Number of kids & 2.04 & 1.98 & 2.04 & -0.06 & 0.000 \\
\hline \multicolumn{6}{|l|}{ Regional Control variables } \\
\hline Vote share - maternity benefit (\%) & 0.45 & 0.48 & 0.43 & 0.05 & 0.000 \\
\hline Inhabitants & 14798 & 17926 & 7041 & 10884 & 0.000 \\
\hline Population density/100 m2 & 787 & 919 & 594 & 325 & 0.000 \\
\hline Urban & 0.16 & 0.19 & 0.07 & 0.13 & 0.000 \\
\hline Agglomeration & 0.46 & 0.57 & 0.53 & 0.04 & 0.000 \\
\hline Rural & 0.38 & 0.23 & 0.41 & -0.17 & 0.000 \\
\hline Income tax (100K married \& 2 kids, \%) & 6.62 & 6.3 & 6.56 & -0.25 & 0.000 \\
\hline Fraction of foreigners (\%) & 17.75 & 19.23 & 16.4 & 2.83 & 0.000 \\
\hline Unemployment rate & 3.1 & 3.36 & 2.97 & 0.39 & 0.000 \\
\hline Home ownership in \% & 42 & 40 & 47 & -8 & 0.000 \\
\hline Fraction of commuters (\%) & 62 & 61 & 63 & -2 & 0.000 \\
\hline
\end{tabular}

Note: The sample is based on the structural survey 2010 and contains 10,133 observations. Treated areas are areas with a level of after-school care above the cut-off, control areas are areas with a level of after-school care below the cut-off 
Table A.5: Income taxes (canton and municipality component)

\begin{tabular}{|c|c|c|c|c|c|c|}
\hline & & \#Municipalities & Average tax & Median tax & Minimum tax & Maximum tax \\
\hline \multirow{3}{*}{1} & $\mathrm{BE}$ & 50 & 8.8 & 8.8 & 8.1 & 9.6 \\
\hline & LU & 53 & 7.7 & 7.8 & 5.9 & 8.5 \\
\hline & Difference & & 1.1 & 1.0 & 2.1 & 1.2 \\
\hline \multirow{3}{*}{2} & $\mathrm{ZH}$ & 13 & 5.9 & 5.9 & 5.1 & 6.3 \\
\hline & LU & 14 & 7.0 & 7.3 & 5.2 & 7.5 \\
\hline & Difference & & -1.2 & -1.4 & -0.2 & -1.2 \\
\hline \multirow{3}{*}{3} & $\mathrm{ZH}$ & 24 & 5.8 & 5.9 & 4.9 & 6.3 \\
\hline & $A G$ & 60 & 6.3 & 6.3 & 5.3 & 6.9 \\
\hline & Difference & & -0.5 & -0.4 & -0.5 & -0.6 \\
\hline \multirow{3}{*}{4} & $\mathrm{ZH}$ & 61 & 5.8 & 5.9 & 4.9 & 6.3 \\
\hline & $A G$ & 40 & 6.1 & 6.2 & 5.3 & 6.9 \\
\hline & Difference & & -0.4 & -0.3 & -0.5 & -0.6 \\
\hline \multirow{3}{*}{5} & $\mathrm{ZH}$ & 79 & 6.0 & 6.0 & 4.9 & 6.3 \\
\hline & SH & 25 & 6.6 & 6.6 & 5.4 & 7.3 \\
\hline & Difference & & -0.7 & -0.6 & -0.6 & -1.0 \\
\hline \multirow{3}{*}{6} & $\mathrm{ZH}$ & 73 & 6.0 & 6.0 & 4.9 & 6.3 \\
\hline & TG & 28 & 6.9 & 7.0 & 6.0 & 7.6 \\
\hline & Difference & & -0.9 & -1.0 & -1.1 & -1.4 \\
\hline \multirow{3}{*}{7} & $\mathrm{ZH}$ & 22 & 6.0 & 6.0 & 5.4 & 6.3 \\
\hline & TG & 49 & 6.7 & 6.8 & 5.1 & 7.6 \\
\hline & Difference & & -0.8 & -0.8 & 0.3 & -1.4 \\
\hline \multirow{3}{*}{8} & $\mathrm{ZH}$ & 22 & 6.0 & 6.0 & 5.4 & 6.3 \\
\hline & SG & 10 & 5.9 & 6.0 & 5.0 & 6.2 \\
\hline & Difference & & 0.1 & 0.0 & 0.3 & 0.0 \\
\hline
\end{tabular}

Note: Taxes are computed for individuals with $100^{\prime} 000 \mathrm{CHF}$ income per year, married, with 2 kids. Taxes are reported in percentage points of total income. They include municipality taxes as well as cantonal taxes. Averages and median are unweighted. 
Table A.6: Preschool and Primary school regulations across cantons (school year 2009/10)

\begin{tabular}{|c|c|c|c|c|c|c|c|c|}
\hline LM & Canton & $\begin{array}{l}\text { Minimum } \\
\text { age at } \\
\text { preschool } \\
\text { entry }\end{array}$ & $\begin{array}{c}\text { Preschool: } \\
\text { hours per } \\
\text { week (last } \\
\text { preschool } \\
\text { year) }\end{array}$ & $\begin{array}{l}\text { Minimum } \\
\text { age at } \\
\text { school entry }\end{array}$ & $\begin{array}{c}\text { Mandatory } \\
\text { bloc hours } \\
\text { (min. } 3.5 \\
\text { hours/ } \\
\text { working day) }\end{array}$ & $\begin{array}{l}\text { Preschool: } \\
\text { Mandatory } \\
\text { offer by } \\
\text { municipality } \\
\text { in years }\end{array}$ & $\begin{array}{l}\text { Attendance: } \\
\text { Fraction of } \\
\text { children with } 1 \\
\text { preschool } \\
\text { year* }\end{array}$ & $\begin{array}{c}\text { Attendance: } \\
\text { Fraction of } \\
\text { children with } 2 \\
\text { preschool years' }\end{array}$ \\
\hline & $\mathrm{BE}$ & 4 yr. 3 m. & $16.5-19.5$ & 6 yr. 3 m. & yes & 1 & $19 \%$ & $80 \%$ \\
\hline \multirow[t]{2}{*}{1} & LU & 4 yr. $9 \mathrm{~m}$. & $15-18$ & 5 yr. $9 \mathrm{~m}$. & yes & 1 & $63 \%$ & $37 \%$ \\
\hline & $\mathrm{ZH}$ & 4 yr. 3 m. & $21-23$ & 6 yr. 3 m. & yes & 2 & $2.20 \%$ & $95.70 \%$ \\
\hline \multirow[t]{2}{*}{2} & LU & 4 yr. 9 m. & $15-18$ & 5 yr. $9 \mathrm{~m}$. & yes & 1 & $63 \%$ & $37 \%$ \\
\hline & $\mathrm{ZH}$ & 4 yr. 3 m. & $21-23$ & 6 yr. 3 m. & yes & 2 & $2.20 \%$ & $95.70 \%$ \\
\hline \multirow[t]{2}{*}{3} & $A G$ & 4 yr. $3 \mathrm{~m}$. & $21-25$ & 6 yr. $3 \mathrm{~m}$. & no & 1 & $2 \%$ & $96 \%$ \\
\hline & $\mathrm{ZH}$ & 4 yr. 3 m. & $21-23$ & 6 yr. 3 m. & yes & 2 & $2.20 \%$ & $95.70 \%$ \\
\hline \multirow[t]{2}{*}{4} & $A G$ & 4 yr. $3 \mathrm{~m}$. & $21-25$ & 6 yr. $3 \mathrm{~m}$. & no & 1 & $2 \%$ & $96 \%$ \\
\hline & $\mathrm{ZH}$ & 4 yr. 3 m. & $21-23$ & 6 yr. 3 m. & yes & 2 & $2.20 \%$ & $95.70 \%$ \\
\hline \multirow[t]{2}{*}{5} & SH & 4 yr. $3 \mathrm{~m}$. & 20.4 & 6 yr. 3 m. & yes & 2 & $1.80 \%$ & $98 \%$ \\
\hline & $\mathrm{ZH}$ & 4 yr. 3 m. & $21-23$ & 6 yr. 3 m. & yes & 2 & $2.20 \%$ & $95.70 \%$ \\
\hline \multirow[t]{2}{*}{6} & TG & 4 yr. $3 \mathrm{~m}$. & $21-25$ & $6 \mathrm{yr}$. & $n o^{* *}$ & 2 & $1 \%$ & $96 \%$ \\
\hline & $\mathrm{ZH}$ & 4 yr. 3 m. & $21-23$ & 6 yr. 3 m. & yes & 2 & $2.20 \%$ & $95.70 \%$ \\
\hline \multirow[t]{2}{*}{7} & TG & 4 yr. $3 \mathrm{~m}$. & $21-25$ & $6 \mathrm{yr}$. & yes & 2 & $1 \%$ & $96 \%$ \\
\hline & $\mathrm{ZH}$ & 4 yr. 3 m. & $21-23$ & 6 yr. $3 \mathrm{~m}$. & yes & 2 & $2.20 \%$ & $95.70 \%$ \\
\hline 8 & SG & $4 \mathrm{yr}$. & 24 & $6 \mathrm{yr}$. & yes & 2 & са. $10 \%$ & са. $90 \%$ \\
\hline
\end{tabular}

Note: *Fraction is computed with respect to all children in their first year in primary school.. **Introduced: 2010 - 2013. 
Table A.7: Distance to major economic hubs (average commuting times by car in minutes)

\begin{tabular}{|c|c|c|c|}
\hline LLM & Canton & $\begin{array}{l}\text { Capital of canton with } \\
\text { childcare regulation }\end{array}$ & $\begin{array}{l}\text { Capital of canton without } \\
\text { childcare regulation }\end{array}$ \\
\hline \multirow{4}{*}{1} & & Berne & Luzern \\
\hline & $\mathrm{BE}$ & 46 & 52 \\
\hline & LU & 71 & 29 \\
\hline & Difference & -25 & 23 \\
\hline \multirow{4}{*}{2} & & Zurich & Luzern \\
\hline & $\mathrm{ZH}$ & 22 & 32 \\
\hline & LU & 41 & 16 \\
\hline & Difference & -19 & 16 \\
\hline \multirow{4}{*}{3} & & Zurich & Aarau \\
\hline & $\mathrm{ZH}$ & 21 & 27 \\
\hline & $A G$ & 31 & 15 \\
\hline & Difference & -10 & 12 \\
\hline \multirow{4}{*}{4} & & Zurich & Aarau \\
\hline & $\mathrm{ZH}$ & 24 & 26 \\
\hline & $A G$ & 29 & 19 \\
\hline & Difference & -5 & 7 \\
\hline \multirow{4}{*}{5} & & Zurich & Schaffhausen \\
\hline & $\mathrm{ZH}$ & 34 & 30 \\
\hline & $\mathrm{SH}$ & 52 & 18 \\
\hline & Difference & -18 & 12 \\
\hline \multirow{4}{*}{6} & & Zurich & Frauenfeld \\
\hline & $\mathrm{ZH}$ & 34 & 45 \\
\hline & TG & 49 & 25 \\
\hline & Difference & -15 & 20 \\
\hline \multirow{4}{*}{7} & & Zurich & Frauenfeld \\
\hline & $\mathrm{ZH}$ & 36 & 38 \\
\hline & TG & 52 & 22 \\
\hline & Difference & -17 & 16 \\
\hline \multirow{4}{*}{8} & & Zurich & St. Gallen \\
\hline & $\mathrm{ZH}$ & 36 & 43 \\
\hline & SG & 52 & 25 \\
\hline & Difference & -16 & 18 \\
\hline
\end{tabular}

Note: The upper canton in each panel is the canton with cantonal childcare regulation, the lower canton is the canton without childcare regulation. Only municipalities in LLMs are included. The displayed distances correspond to unweighted averages over municipalities in each of the canton. 
Table A.8: 'Placebo'-estimation using Men and Women age 18-42 without children

\begin{tabular}{|c|c|c|c|c|c|}
\hline & $\begin{array}{l}\text { Childcare } \\
\text { above the }\end{array}$ & $\begin{array}{l}\text { Childcare } \\
\text { below the }\end{array}$ & Effect & \multicolumn{2}{|c|}{$\begin{array}{l}95 \% \text { Confidence } \\
\text { interval }\end{array}$} \\
\hline & (1) & (2) & (3) & \multicolumn{2}{|c|}{ (4) } \\
\hline \multicolumn{6}{|l|}{ Panel A) Swiss Women without children (age <42) } \\
\hline Employment (binary) & 0.76 & 0.75 & 0.01 & -0.07 & 0.15 \\
\hline Full-time (binary) & 0.55 & 0.51 & 0.04 & -0.06 & 0.22 \\
\hline Part-time (binary; < 36h/week) & 0.21 & 0.24 & -0.04 & -0.13 & 0.06 \\
\hline Low part-time (binary; < 20h/week) & 0.06 & 0.07 & -0.01 & -0.08 & 0.03 \\
\hline Intermediate part-time (binary; 20-27h/week) & 0.05 & 0.05 & 0.00 & -0.07 & 0.04 \\
\hline High part-time (binary; 28-35h/week) & 0.10 & 0.12 & -0.02 & -0.06 & 0.08 \\
\hline Effect of Reform on Child Care Supply (First Stage) & 0.72 & 0.30 & $0.42^{\star \star *}$ & 0.29 & 0.57 \\
\hline \multicolumn{6}{|l|}{ Panel B) Swiss Men without children (age <42) } \\
\hline Employment (binary) & 0.78 & 0.78 & -0.01 & -0.15 & 0.12 \\
\hline Full-time (binary) & 0.67 & 0.71 & -0.04 & -0.19 & 0.09 \\
\hline Part-time (binary; < 36h/week) & 0.10 & 0.07 & 0.03 & -0.06 & 0.11 \\
\hline Low part-time (binary; < 20h/week) & 0.05 & 0.02 & 0.03 & -0.04 & 0.08 \\
\hline Intermediate part-time (binary; 20-27h/week) & 0.02 & 0.02 & 0.00 & -0.05 & 0.03 \\
\hline High part-time (binary; 28-35h/week) & 0.03 & 0.03 & 0.00 & -0.03 & 0.07 \\
\hline Effect of Reform on Child Care Supply (First Stage) & 0.69 & 0.29 & $0.39^{* * *}$ & 0.25 & 0.57 \\
\hline
\end{tabular}

Note: ${ }^{*}$ significant at the $1 \%$; ${ }^{* *}$ significant at the $5 \% ;{ }^{*}$ significant at the $10 \%$ significance level. Estimates are weighted averages of the instrumental variable estimates for each LLM. The underlying weights correspond to the number of compliers in the respective LLM. The instrument is based on the enforcement of after-school care supply in the cantonal school law. The sample corresponds to 16,381 observations in the case of women and 18,652 observations in the case of men. 
Table A.9: Local childcare supply prior to and after changing the municipality of residence

\begin{tabular}{|c|c|c|c|c|c|c|}
\hline \multicolumn{7}{|c|}{ Coverage with after-school care (slots per child), before and after moving to a new municipality } \\
\hline \multicolumn{7}{|c|}{ Panel A: Female (age 18-62) } \\
\hline \multirow{4}{*}{ Age } & \multirow{2}{*}{\multicolumn{3}{|c|}{$\begin{array}{l}\text { Municipality inside of LLM area after } \\
\text { change of residence }\end{array}$}} & \multirow{2}{*}{\multicolumn{3}{|c|}{$\begin{array}{l}\text { Municipality inside of LLM area } \\
\text { before change of residence }\end{array}$}} \\
\hline & & & & & & \\
\hline & \multirow[t]{2}{*}{ Observations } & \multicolumn{2}{|c|}{$\begin{array}{l}\text { Coverage rate } \\
\text { (Slots per child) }\end{array}$} & Observations & \multicolumn{2}{|c|}{$\begin{array}{l}\text { Coverage rate } \\
\text { (Slots per child) }\end{array}$} \\
\hline & & Before & After & & Before & After \\
\hline (1) & (2) & (3) & (4) & (5) & (6) & (7) \\
\hline $18-22$ & 289 & 0.07 & 0.07 & 285 & 0.06 & 0.09 \\
\hline $23-27$ & 470 & 0.08 & 0.07 & 504 & 0.07 & 0.1 \\
\hline $28-32$ & 429 & 0.1 & 0.07 & 431 & 0.07 & 0.1 \\
\hline $33-37$ & 295 & 0.11 & 0.06 & 267 & 0.08 & 0.08 \\
\hline $38-42$ & 189 & 0.09 & 0.06 & 195 & 0.07 & 0.09 \\
\hline $43-47$ & 164 & 0.09 & 0.07 & 170 & 0.07 & 0.08 \\
\hline $48-52$ & 130 & 0.08 & 0.06 & 131 & 0.07 & 0.07 \\
\hline $53-57$ & 86 & 0.09 & 0.06 & 94 & 0.08 & 0.08 \\
\hline $58-62$ & 53 & 0.1 & 0.06 & 55 & 0.07 & 0.07 \\
\hline \multicolumn{7}{|c|}{ Panel B: Male (age 18-62) } \\
\hline & \multicolumn{3}{|c|}{$\begin{array}{l}\text { Municipality inside of LLM area } \\
\text { after change of residence }\end{array}$} & \multicolumn{3}{|c|}{$\begin{array}{l}\text { Municipality inside of LLM area } \\
\text { before change of residence }\end{array}$} \\
\hline \multirow[t]{2}{*}{ Age } & Observations & \multicolumn{2}{|c|}{$\begin{array}{l}\text { Coverage rate } \\
\text { (Slots per child) }\end{array}$} & Observations & \multicolumn{2}{|c|}{$\begin{array}{l}\text { Coverage rate } \\
\text { (Slots per child) }\end{array}$} \\
\hline & & Before & After & & Before & After \\
\hline (1) & (2) & (3) & $(4)$ & (5) & (6) & (7) \\
\hline $18-22$ & 202 & 0.07 & 0.07 & 207 & 0.06 & 0.09 \\
\hline $23-27$ & 402 & 0.07 & 0.07 & 411 & 0.06 & 0.1 \\
\hline $28-32$ & 437 & 0.1 & 0.07 & 429 & 0.08 & 0.1 \\
\hline $33-37$ & 304 & 0.1 & 0.07 & 316 & 0.07 & 0.1 \\
\hline $38-42$ & 254 & 0.11 & 0.07 & 232 & 0.08 & 0.09 \\
\hline $43-47$ & 185 & 0.09 & 0.07 & 182 & 0.08 & 0.08 \\
\hline $48-52$ & 136 & 0.11 & 0.07 & 125 & 0.07 & 0.08 \\
\hline 53-57 & 90 & 0.09 & 0.06 & 99 & 0.06 & 0.08 \\
\hline $58-62$ & 77 & 0.11 & 0.06 & 72 & 0.08 & 0.07 \\
\hline
\end{tabular}

Note: Sample based on all individuals age 18-62 who have migrated between two municipalities within the last 12 months before the survey. Columns 2-4: Individuals who are living inside the LLM area after migration. To make sure we do not neglect people who leave the area covered by the LLMS, Columns 5-7 refer to individuals who have been living in the LLM area before migration. The two samples are overlapping, i.e. both contain individuals who have been living in the LLM area both before and after migrating to a new municipality. 


\section{Appendix B}

\section{B.1. Construction of Local Labor Markets}

To construct local labor markets (LLMs) we draw upon the 160 Swiss so-called MS regions (Mobilité Spatiale regions), which were defined in 1982 by the Statistical office of Switzerland based on commuting behavior. We combine all MS regions that lie within a limited commuting area (30 minutes by car) and that lie along a cantonal border that signifies a division in the cantonal regulation of after-school care services. ${ }^{21}$ We drop all LLMs i) where the area on one side of the cantonal border contains the majority of the respective cantonal population; ${ }^{22}$ ii) where the populations on both sides of the cantonal border differ strongly in their preferences related to work and family; and iii) where is no clear division in the preferences related to work and family between the municipalities inside and outside the LLM in at least one of the two cantons considered in the respective LLM. Section B.2 provides empirical evidence for these restrictions.

The resulting LLMs are either municipalities at the cantonal division of Bern with the surrounding cantons (here Lucerne) or municipalities at the cantonal division of Zurich with the surrounding cantons (here Aargau, Lucerne, Schaffhausen, St. Gallen and Thurgau). ${ }^{23}$ Figure 1 represents the geographical area covered by the LLMs. While the geographical area is rather small it contains $20 \%$ of the overall Swiss population (and $30 \%$ of the overall Swiss German population).

${ }^{21}$ Note that LLMs can overlap. Yet, we only consider LLMs that contain exactly one cantonal border, i.e. that contain municipalities from exactly two different cantons.

${ }^{22}$ We deviate twice from this condition, in LLM 5 and in LLM 7. Yet, the discontinuity regarding the cantonal legislation and thus the after-school care provision across the cantonal border is in both cases driven by the other cantonal part. In other words, there is at least one cantonal part where the population living inside the LLM got outvoted by the population living outside the LLM.

23 There are two further potential sets of cantonal borders: borders of the canton Solothurn and its neighbor cantons, and borders between the canton Geneva and Vaudt. Due to the lack of data on after-school care for Solothurn, we cannot use any LLM based on Solothurn and the neighboring cantons. The LLM along the cantonal border between Geneva and Vaud cannot be used for our analysis, as there is no strong heterogeneity in the preferences regarding work and family within the respective cantons. One further potential LLM stretching over the cantonal border between Zurich and Zug is excluded as income taxes - an issue discussed in Section 5.2 - are substantially different in both cantons. 


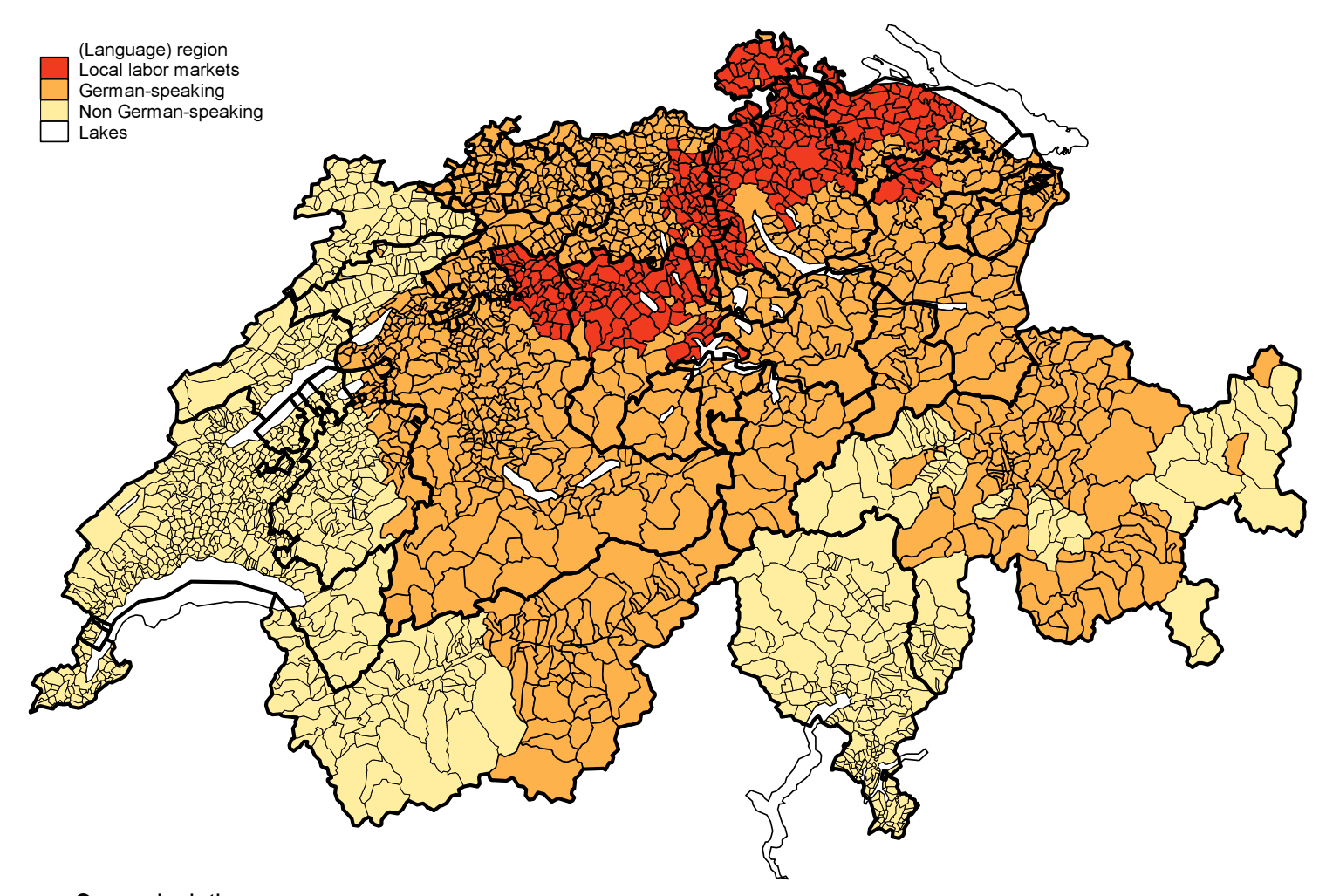

Source: Own calculations

\section{B.2. Empirical Evidence for the Conditions imposed on Local Labor Markets}

Table B.1 lists the resulting LLMs. Bern and Zurich are cantons that by 2010 (the year of our data) explicitly enforce after-school care - and thus observations belonging to these cantons are assigned the value one for the IV. The remaining cantons Aargau, Lucerne, Schaffhausen, St. Gallen and Thurgau, do not explicitly enforce after-school care in their cantonal legislation by 2010 - and thus observations belonging to these cantons are assigned the value zero for the IV.

Table B.1, Column 4 provides descriptive evidence for the cantonal borders to be monotone and strong IVs. Cantonal laws enforcing after-school care supply indeed correlate positively with after-school care provision. With the exception of one LLM, there is a higher supply of after-school care in the municipalities of the canton legally enforcing after-school 
care provision than in the municipalities of the canton not legally enforcing after-school care provision. $^{24}$

Table B.1, Column 5 and 6 provide some supportive evidence that the cantonal school law is exogenous to the preferences related to work and family of the population residing in municipalities within the LLM. First, the municipalities included in the LLMs correspond on at least one side of the cantonal border to the minority of the respective cantonal population. Second, the populations on both sides of the cantonal border share the same preferences regarding work and family. To address this issue we rely on the results of the referendum on maternity benefits (September 26, 2004). Results on the referendum are rather similar across the cantonal border within each LLM. Yet, on at least one side of the cantonal border, the remaining cantonal population outside the LLM outvotes the population living inside the LLM.

Using the example of the LLM along the cantonal border between Bern and Lucerne helps to illustrate this issue. Inside the LLM the referendum failed on both sides of the cantonal border. It also failed in the remaining municipalities of the canton Lucerne. Yet, the respective municipalities belonging to the canton Bern were outvoted by the remaining cantonal population. Hence, while citizens inside the LLM are rather similar regarding their preferences related to work and family, the remaining cantonal population outside the LLM differs, in at least one of the two cantons, strongly with respect to such preferences. As a result, differences in the existing cantonal laws related to work and family might arise, but are unlikely to be driven by the population living in the municipalities belonging to the LLM.

\footnotetext{
${ }^{24}$ When aggregating the estimates for the different LLMs we weight each estimate by the number of compliers inside the respective LLM and thus, any defiers - municipalities that decrease their after-school care due to the legal enforcement are not taken into consideration.
} 


\section{Internet Appendix (Not for Publication)}

Table I.1: Cantonal involvement regarding childcare provision

\begin{tabular}{|c|c|c|c|c|c|}
\hline Canton & $\begin{array}{l}\text { Reference to } \\
\text { childcare in } \\
\text { cantonal } \\
\text { legislation }\end{array}$ & $\begin{array}{l}\text { Information/ } \\
\text { Coordination/ } \\
\text { Counseling }\end{array}$ & Reglementation* & Approval & $\begin{array}{l}\text { Financial } \\
\text { contribution }\end{array}$ \\
\hline & (1) & (2) & (3) & (4) & (5) \\
\hline$A G$ & No & Yes & No & No & Yes \\
\hline $\mathrm{Al}$ & No & No & Yes & Yes & No \\
\hline AR & Yes & No & No & No & No \\
\hline$B E$ & Yes & Yes & Yes & No & Yes \\
\hline $\mathrm{BL}$ & Yes & Yes & No & No & Yes \\
\hline BS & Yes & No & Yes & Yes & Yes \\
\hline FR & Yes & Yes & Yes & Yes & No \\
\hline GE & No & No & No & No & No \\
\hline GL & No & No & Partially & Yes & Yes \\
\hline GR & Yes & No & Yes & Yes & Yes \\
\hline JU & Yes & Yes & Yes & Yes & Yes \\
\hline LU & Yes & Yes & No & No & Yes \\
\hline $\mathrm{NE}$ & Yes & Yes & Yes & Yes & Yes \\
\hline NW & Yes & Yes & Yes & Yes & No \\
\hline OW & Yes & Yes & Yes & Yes & Yes \\
\hline SG & Yes & No & No & No & No \\
\hline $\mathrm{SH}$ & No & No & Partially & No & No \\
\hline so & Yes & Yes & Yes & Yes & Yes \\
\hline$S Z$ & No & Yes & Partially & No & No \\
\hline TG & Yes & Yes & Yes & Yes & No \\
\hline $\mathrm{Tl}$ & Yes & No & Yes & Yes & Yes \\
\hline UR & No & Yes & No & No & Yes \\
\hline VD & Yes & Yes & Yes & Yes & Yes \\
\hline VS & Yes & Yes & Yes & No & Yes \\
\hline ZG & Yes & Yes & Partially & No & No \\
\hline $\mathrm{ZH}$ & Yes & Yes & Yes & No & No \\
\hline
\end{tabular}

Source: Internet platform Beruf und Familie (2008). * Reglementation is under the responsibility of either the canton (= Yes), the municipality (= No) or both (= Partially). 
Table I.2: Propensity score estimations for each local labor market separately

\begin{tabular}{|c|c|c|c|c|c|c|c|c|c|c|c|c|}
\hline \multirow[b]{2}{*}{ Low education } & \multicolumn{2}{|l|}{ LLM 9} & \multicolumn{2}{|c|}{ LLM 13} & \multicolumn{2}{|c|}{ LLM 14} & \multicolumn{2}{|c|}{ LLM 16} & \multicolumn{2}{|l|}{ LLM 17} & \multicolumn{2}{|l|}{ LLM 18} \\
\hline & 0.009 & & 0.451 & $* * *$ & 0.300 & $* * *$ & 0.046 & & -0.123 & & 0.023 & \\
\hline High education & -0.217 & $* *$ & 0.087 & & -0.001 & & -0.146 & & -0.051 & & -0.066 & \\
\hline Age & -0.046 & & -0.007 & & 0.063 & & 0.128 & * & 0.190 & $* * *$ & 0.110 & \\
\hline Age squared & 0.000 & & 0.000 & & -0.001 & & -0.001 & & -0.002 & $* * *$ & -0.001 & \\
\hline Partner & -0.273 & & 0.050 & & -0.027 & & 0.010 & & 0.267 & * & 0.152 & \\
\hline Local referendum results & 9.377 & $* * *$ & 6.253 & $* * *$ & -3.333 & $* * *$ & 3.725 & $* * *$ & 11.196 & $* * *$ & 13.427 & $* * *$ \\
\hline \# children & -0.093 & & -0.038 & & 0.022 & & -0.207 & $* * *$ & -0.176 & $* * *$ & -0.129 & * \\
\hline \# children age 0-4 & -0.054 & & 0.008 & & -0.100 & ** & 0.176 & $* *$ & 0.072 & & 0.054 & \\
\hline \# children age 5-12 & 0.114 & & 0.040 & & -0.022 & & 0.145 & $* *$ & 0.127 & $* *$ & 0.129 & \\
\hline Constant & -3.131 & $* *$ & -3.618 & $* * *$ & 0.513 & & -3.359 & ** & -8.505 & $* * *$ & -8.903 & $* * *$ \\
\hline Observations & 1440 & & 1595 & & 2050 & & 1303 & & 1385 & & 1177 & \\
\hline
\end{tabular}

Note: This table displays the coefficients resulting from the propensity score estimation. In other words, these coefficients stem from a probit estimation of the instrument (binary variable indicating whether the individual lives in a canton enforcing after-school care provision) on the set of control variables listed above. ${ }^{*}$ significant at the $1 \%$; ${ }^{* *}$ significant at the $5 \%$; ${ }^{*}$ significant at the $10 \%$ significance level. 
Table I.3: External validity - Descriptive statistics pooled sample versus "complier sample"

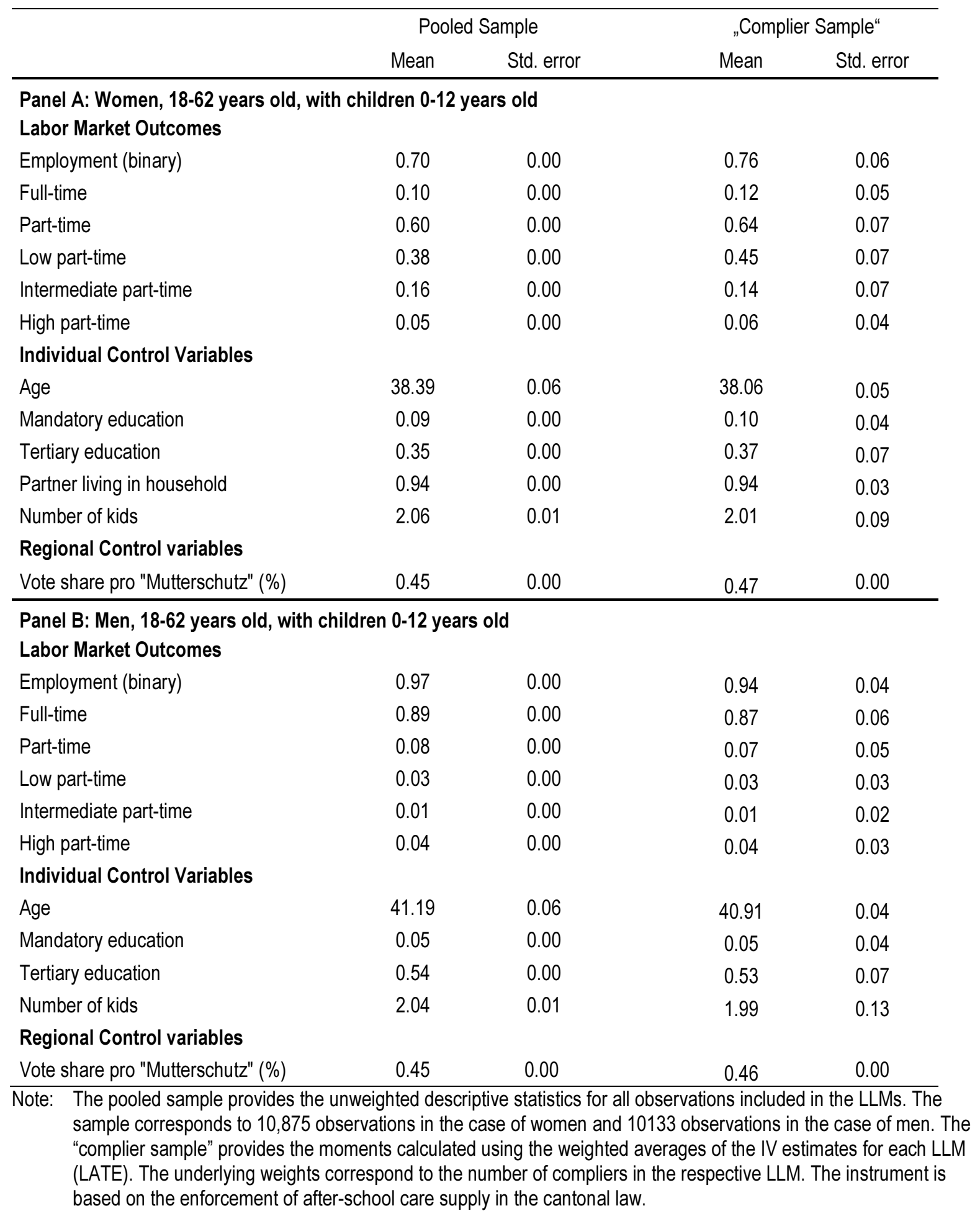


Table I.4: External Validity - Men and women, age 18-62 with at least one child age 0-12

\begin{tabular}{|c|c|c|c|c|}
\hline & \multirow{2}{*}{$\begin{array}{l}\text { LLM } \\
\text { Mean }\end{array}$} & \multirow{2}{*}{$\begin{array}{c}\text { German } \\
\text { speaking } \\
\text { Switzerland } \\
\text { Mean }\end{array}$} & \multicolumn{2}{|c|}{$\begin{array}{l}\text { LLM-German speaking } \\
\text { Switzerland }\end{array}$} \\
\hline & & & Difference & p-val. \% \\
\hline \multicolumn{5}{|l|}{ Labor Market Outcomes } \\
\hline Employment (binary) & 0.83 & 0.84 & 0.00 & 0.213 \\
\hline Full-time & 0.48 & 0.47 & 0.01 & 0.127 \\
\hline Part-time & 0.35 & 0.36 & -0.01 & 0.011 \\
\hline Low part-time & 0.21 & 0.20 & 0.01 & 0.006 \\
\hline Intermediate part-time & 0.09 & 0.10 & -0.01 & 0.000 \\
\hline High part-time & 0.05 & 0.06 & -0.01 & 0.000 \\
\hline \multicolumn{5}{|l|}{ Treatment/Instrument } \\
\hline After-school care: Slots per child & 0.06 & 0.09 & -0.03 & 0.000 \\
\hline Reform canton (binary) & 0.32 & 0.43 & -0.11 & 0.000 \\
\hline \multicolumn{5}{|l|}{ Individual Control Variables } \\
\hline Age & 39.74 & 39.79 & -0.05 & 0.427 \\
\hline Female & 0.52 & 0.52 & 0.00 & 0.884 \\
\hline Mandatory education & 0.07 & 0.08 & -0.01 & 0.003 \\
\hline Secondary education & 0.48 & 0.44 & 0.03 & 0.000 \\
\hline Tertiary education & 0.44 & 0.47 & -0.02 & 0.000 \\
\hline Married & 0.91 & 0.91 & 0.00 & 0.983 \\
\hline Single & 0.06 & 0.06 & 0.00 & 0.739 \\
\hline Divorced & 0.03 & 0.03 & 0.00 & 0.835 \\
\hline Widowed & 0.00 & 0.00 & 0.00 & 0.062 \\
\hline Partner living in household & 0.97 & 0.96 & 0.00 & 0.036 \\
\hline Number of kids & 2.05 & 2.04 & 0.01 & 0.112 \\
\hline \multicolumn{5}{|l|}{ Regional Control variables } \\
\hline Vote share pro "Mutterschutz" in municipality & 0.45 & 0.48 & -0.03 & 0.000 \\
\hline No. of inhabitants in 2010 & 14864 & 66742 & -51878 & 0.000 \\
\hline Population density per 100 square meters & 791 & 1340 & -548 & 0.000 \\
\hline Urban & 0.16 & 0.31 & -0.15 & 0.000 \\
\hline Agglomeration & 0.46 & 0.39 & 0.06 & 0.000 \\
\hline Rural & 0.38 & 0.30 & 0.08 & 0.000 \\
\hline Income tax at $100 \mathrm{~K}$ married $\& 2$ kids (\%) & 6.62 & 6.61 & 0.01 & 0.432 \\
\hline Unemployment rate & 3.11 & 3.08 & 0.03 & 0.024 \\
\hline Home ownership in \% & 42 & 37 & 5 & 0.000 \\
\hline Fraction of commuters (\%) & 59 & 51 & 9 & 0.000 \\
\hline
\end{tabular}


Table I.5: Weighting scheme based on share of compliers:

Results for Men and Women with children (age 0-12)

\begin{tabular}{|c|c|c|c|c|c|}
\hline & $\begin{array}{l}\text { Municipalities with } \\
\text { cantonal } \\
\text { enforcement of } \\
\text { after-school care }\end{array}$ & $\begin{array}{l}\text { Municipalities } \\
\text { without cantonal } \\
\text { enforcement of } \\
\text { after-school care }\end{array}$ & Effect & \multicolumn{2}{|c|}{$\begin{array}{c}95 \% \\
\text { Confidence } \\
\text { interval }\end{array}$} \\
\hline & (1) & (2) & (3) & \multicolumn{2}{|c|}{ (4) } \\
\hline \multicolumn{6}{|c|}{ Panel A) Swiss Women with children (age 0-12) } \\
\hline Employment (binary) & 0.76 & 0.68 & 0.08 & -0.04 & 0.21 \\
\hline Full-time (binary) & 0.12 & 0.03 & $0.09^{*}$ & 0.00 & 0.19 \\
\hline Part-time (binary; < 36h/week) & 0.64 & 0.65 & -0.01 & -0.14 & 0.13 \\
\hline Low part-time (binary; < 20h/week) & 0.45 & 0.43 & 0.02 & -0.13 & 0.16 \\
\hline Intermediate part-time (binary; 20-27h/week) & 0.14 & 0.16 & -0.03 & -0.19 & 0.09 \\
\hline High part-time (binry; 28-35h/week) & 0.06 & 0.06 & 0.00 & -0.06 & 0.09 \\
\hline \multicolumn{6}{|l|}{ Effect of Instrument on treatment } \\
\hline \multicolumn{6}{|l|}{ Panel B) Swiss Men with children (age 0-12) } \\
\hline Employment (binary) & 0.94 & 0.96 & -0.02 & -0.10 & 0.03 \\
\hline Full-time (binary) & 0.87 & 0.97 & $-0.09^{*}$ & -0.22 & 0.02 \\
\hline Part-time (binary; < 36h/week) & 0.07 & -0.01 & 0.07 & -0.02 & 0.18 \\
\hline Low part-time (binary; < 20h/week) & 0.03 & 0.00 & $0.02^{*}$ & -0.01 & 0.09 \\
\hline Intermediate part-time (binary; 20-27h/week) & 0.01 & -0.02 & $0.02^{*}$ & -0.01 & 0.06 \\
\hline High part-time (binry; 28-35h/week) & 0.04 & 0.01 & 0.03 & -0.06 & 0.08 \\
\hline
\end{tabular}

Effect of Instrument on treatment

Note: * significant at the $1 \%$; ${ }^{* *}$ significant at the $5 \%$; ${ }^{*}$ significant at the $10 \%$ significance level.

Above estimates are weighted averages of the instrumental variable estimates for each LLM. The underlying weights correspond to the share of compliers in the respective LLM. The instrument is based on the enforcement of afterschool care supply in the cantonal school law. The sample corresponds to 10875 observations in the case of women and 10133 observations in the case of men. 
Table I.6: Weighting scheme based on number of observations:

Results for Men and Women with children (age 0-12)

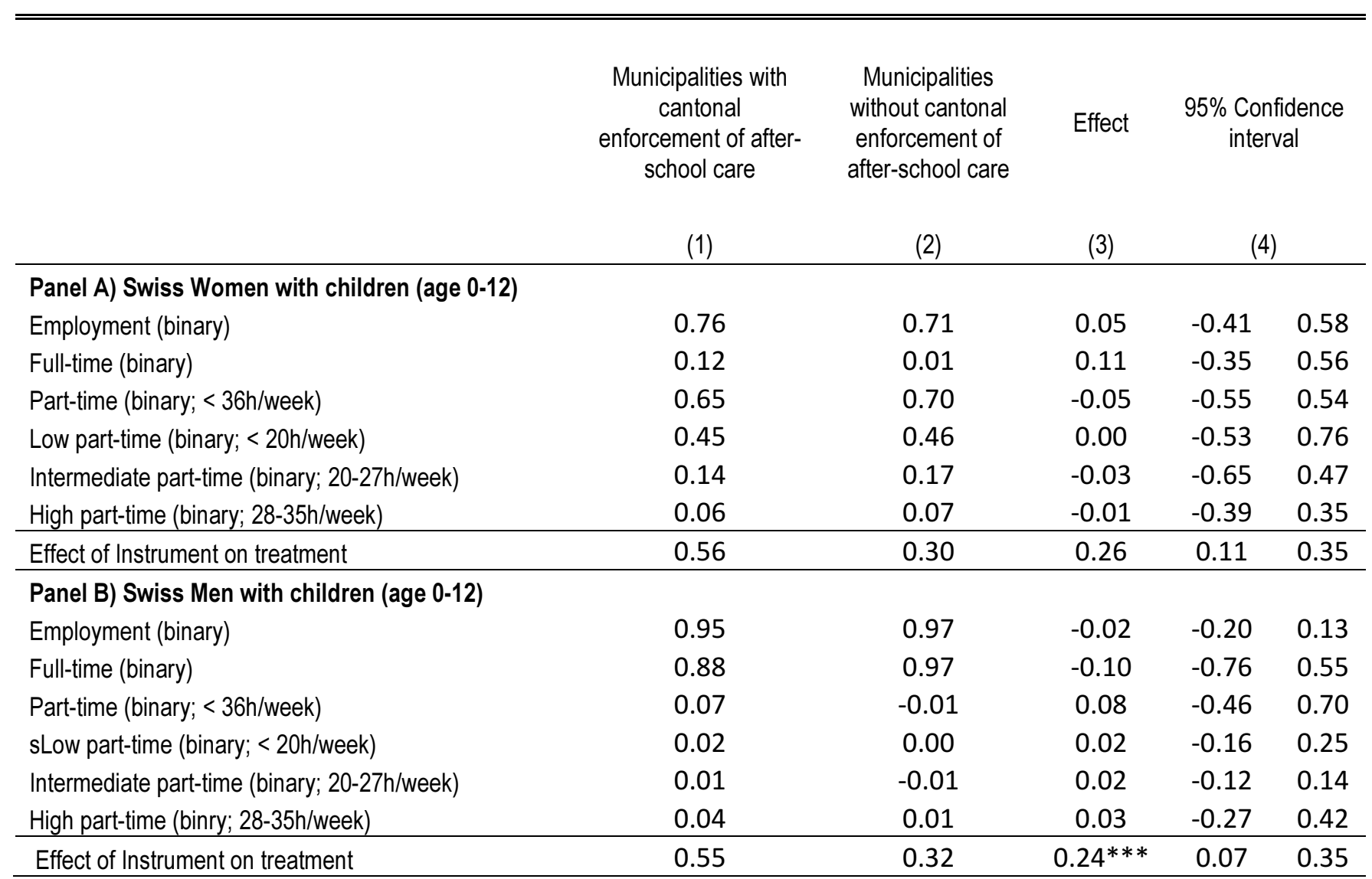

Note: * significant at the $1 \%$; ** significant at the $5 \%$; * significant at the $10 \%$ significance level.

Above estimates are weighted averages of the instrumental variable estimates for each LLM. The underlying weights correspond to the number of observations in the respective LLM. The instrument is based on the enforcement of after-school care supply in the cantonal school law. The sample corresponds to 10875 observations in the case of women and 10133 observations in the case of men. 
Table I.7: Weighting scheme based on number of observations with zero weights given to

LLMs with negative first stage results: Results for Men and Women with children (age

0-12)

\section{Municipalities with cantonal \\ enforcement of after- school care}

Municipalities without cantonal enforcement of after-school care
Effect
interval

(3)

(2)

0.69

0.09

$-0.13$

(4)

\begin{tabular}{llcccc}
\hline Panel A) Swiss Women with children (age 0-12) & & & & & \\
Employment (binary) & 0.78 & 0.69 & 0.09 & -0.13 & 0.56 \\
Full-time (binary) & 0.12 & 0.01 & $0.12^{*}$ & -0.02 & 0.62 \\
Part-time (binary; <36h/week) & 0.65 & 0.69 & -0.03 & -0.39 & 0.26 \\
Low part-time (binary; < 20h/week) & 0.45 & 0.46 & -0.01 & -0.39 & 0.40 \\
Intermediate part-time (binary; 20-27h/week) & 0.13 & 0.16 & -0.03 & -0.60 & 0.17 \\
High part-time (binry; 28-35h/week) & 0.07 & 0.06 & 0.01 & -0.11 & 0.39 \\
\hline Effect of Instrument on treatment & 0.63 & 0.25 & $0.39 * * *$ & 0.25 & 0.51 \\
\hline Panel B) Swiss Men with children (age 0-12) & & & & & \\
Employment (binary) & 0.95 & 0.97 & -0.03 & -0.24 & 0.03 \\
Full-time (binary) & 0.88 & 1.00 & $-0.12^{*}$ & -0.95 & 0.00 \\
Part-time (binary; <36h/week) & 0.07 & -0.03 & 0.10 & -0.06 & 0.77 \\
Low part-time (binary; <20h/week) & 0.03 & 0.00 & 0.03 & -0.04 & 0.27 \\
Intermediate part-time (binary; 20-27h/week) & 0.01 & -0.02 & 0.03 & -0.03 & 0.18 \\
High part-time (binry; 28-35h/week) & 0.04 & 0.00 & 0.04 & -0.06 & 0.44 \\
\hline Effect of Instrument on treatment & 0.63 & 0.27 & $0.36^{* * *}$ & 0.24 & 0.49 \\
\hline
\end{tabular}

Note: ${ }^{*}$ significant at the $1 \% ;{ }^{* *}$ significant at the $5 \% ;{ }^{*}$ significant at the $10 \%$ significance level. Above estimates are weighted averages of the instrumental variable estimates for each LLM. The underlying weights correspond to the number of observations in the respective LLM with zero weights given to defiers. The instrument is based on the enforcement of after-school care supply in the cantonal school law. The sample corresponds to 10875 observations in the case of women and 10133 observations in the case of men. 